\title{
Study of the influence of physical, chemical and biological conditions that influence the deterioration and protection of Underwater Cultural Heritage
}

\author{
Manuel Bethencourt ${ }^{\mathrm{a}, *}$, Tomás Fernández-Montblanc ${ }^{\mathrm{b}}$, Alfredo Izquierdo ${ }^{\mathrm{b}}$, \\ Manuel María González-Duarte ${ }^{\mathrm{c}}$, Cristian Muñoz-Mas ${ }^{\text {a }}$

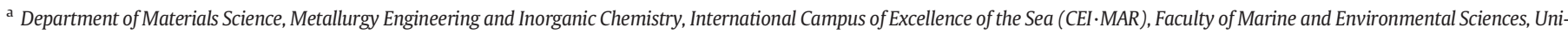 \\ versity of Cadiz, Avda. República Saharaui s/n, 11510 Puerto Real, Cádiz, Spain

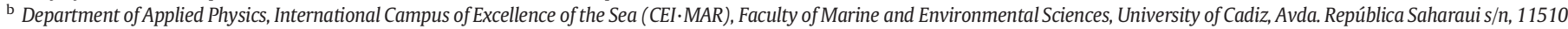 \\ Puerto Real, Cádiz, Spain

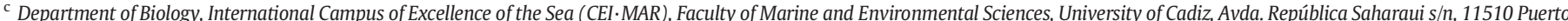 \\ Real, Cádiz, Spain
}

\section{H I G H L I G H T S}

- A multidisciplinary approach is necessary to understand how the main marine environmental variables can influence the formation, conservation or degradation of Underwater Cultural Heritage.

- Following the guidelines of the UNESCO 2001 Convention, a holistic and interdisciplinary approach based on the development of four of its thirty-six Rules Rules was applied.

- After monitoring these variables, we have established correlations between the environmental conditions and the degradation suffered by archaeological artifacts.

- A non-destructive technique was developed to obtain information from marine archaeological iron artefacts in historical shipwrecks.

- The effectiveness of cathodic protection as a temporary measure for in situ conservation was evaluated.

\section{A R T I C L E I N F O}

\section{Article history:}

Received 9 May 2017

Received in revised form 1 September 2017

Accepted 1 September 2017

Available online $\mathrm{xxxx}$
G R A P H I C A L A B S T R A C T

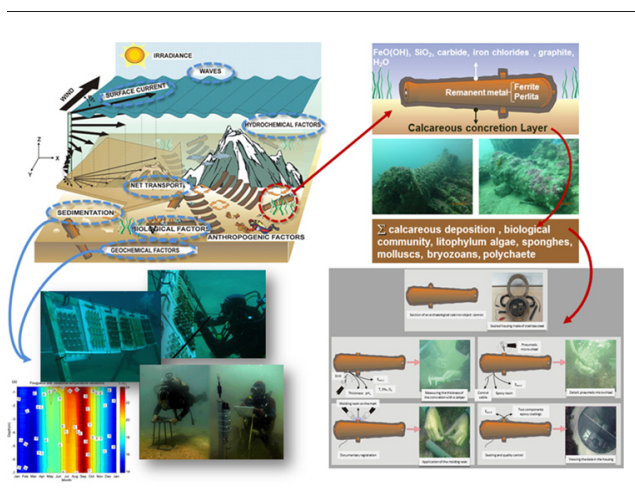

\section{A B S T R A C T}

Two wrecks related to the Battle of Trafalgar (1805) were studied. Following the guidelines of the UNESCO-2001 Convention for the Protection of the Underwater Cultural Heritage, a holistic and interdisciplinary approach based on the development of four of the thirty-six Rules of this international agreement was applied. A nondestructive survey technique was developed to obtain information from the scattered cannons and anchors without altering their condition (Rule 4). The work performed provided information about the origin of both wrecks, the Fougueux and the Bucentaure, two ships of the line of the French Navy, and allowed to characterize the state of

\footnotetext{
* Corresponding author.

E-mail address: manuel.bethencourt@uca.es (M. Bethencourt).
} 
Editor: D. Barcelo

\section{Keywords:}

Shipwreck

Management

Conservation

Monitoring

Geochemical characteristics

Corrosion conservation at each site without jeopardizing their future conservation in the marine environment. In addition, measurements of the main physical, chemical and biological variables allowed correlating the conservation status at each site with the marine environmental conditions (Rule 15). Thus, in Fougueux shipwreck large iron objects are corroding at a higher rate (between 0.180 and $0.246 \mathrm{mmpy}$ ) due to high sediment remobilization and transport induced by waves at this site, causing damage by direct mechanical effect on metallic material and by removing the layer of corrosion products developed on the artefacts. Meanwhile artillery on Bucentaure site, covered with thick layers of biological concretion, is well preserved, with lower corrosion rates (0.073 to $0.126 \mathrm{mmpy}$ ), and archaeological information is guaranteed. Finally, the effectiveness of the cathodic protection as a temporary measure for in situ conservation (Rule 1) was evaluated on a cannon. The use of a sacrificial anode after 9 months reduced the average corrosion rate (from 0.103 to $0.064 \mathrm{mmpy}$ ) and the percent of corrosion rate in $37.9 \%$. These results are very useful for developing a decision making system of the Site Management Program, based on predictive models of artefacts permanence and risk factors in the marine environment (Rule 25).

(c) 2017 Elsevier B.V. All rights reserved.

\section{Introduction}

The increasing rate of discoveries of shipwrecks and other submerged structures poses the challenge of developing alternative methods of storage and stabilization of these archaeological findings. But the problem that arises is threefold: firstly, the initial storage, stabilization and conservation of these findings are very expensive; secondly, full and proper conservation depends largely on the availability of human and material resources; thirdly, it is not always convenient or necessary to excavate an underwater archaeological site, since a part of cultural resources can be managed and stabilized in situ (Bergstrand and Godfrey, 2007). The excavation is a destructive and expensive process and therefore should be chosen as the final solution only when objects or obtained information are unique or at risk of disappearing. This in situ conservation approach has been endorsed in Rule 1 of the Guidelines to the Annex of the UNESCO 2001 Convention for the Protection of the Underwater Cultural Heritage (UCH) (UNESCO, n.d.), which considers the protection of UCH through in situ preservation as the first option.

The in situ conservation involves several scientific areas such as materials science, marine chemistry, physical oceanography and meteorology, marine biology, archaeology and conservation. This plurality implies an added difficulty to consolidate research groups working on different problems related to the study and conservation of UCH. However, there are international groups that have made contributions from any of these fields. Some of these groups have been temporally associated in multidisciplinary projects, performing the most recent and relevant contributions in the treated subject.

So, between 2001 and 2004, The MoSS Project (Monitoring, Safeguarding and Visualizing North-European Shipwreck Sites) (MoSS Project, 2004), brought together the efforts of research groups from six European countries. In this project, for the first time, a scientific methodology was applied to the study of the environmental variables in four underwater archaeological sites. The important outcomes of such enormous effort have been published on a website and in several research papers highlighting the problems of working with four wrecks located in marine and inland waters of very different types and temporality: the wreck of Darss Cog (between 1277 and 1293) in the German Baltic, the flotsam Burgzand Noord-10 (1553) in waters near Amsterdam, the merchant Vrouw Maria (1771) on the Finnish Baltic, and the steam E. Nordevall (1856) in the Swedish lake Vättern.

It is remarkable also the work carried out between 2002 and 2005 within the RAAR Project (Reburial and Analyses of Archaeological Remains) (RAAR Project, 2005) whose main objective was to assess the re-burial as an alternative method for long-term storage and preservation of underwater archaeological objects. The researchers involved in this project covered wider areas of knowledge than in MoSS. Studies with modern and archaeological materials were carried out in the port location of Marstrand, north of Sweden, taking advantage of the presence in the area of the remains of the frigate Fredricus (1719).
Similarly it is necessary to highlight the efforts made within the MACHU Project (Managing Cultural Heritage Underwater) (MACHU Project, 2009). It was a three-year project (2007-2009) with 7 partner countries, like MoSS sponsored by the Culture 2000 Program of the European Union. The main goal of the MACHU project was to find new and better ways for effective management of UCH and to improve the access to information for academic purposes, for policy makers and the public in general.

On the other hand, Rule 4 of the Guidelines states that activities should not affect a site more than necessary, and that the overarching aim is to preserve and protect a site as much and as best as possible. Furthermore, this Rule emphasizes the need to use non-destructive techniques and survey methods rather than traditional digging and the recovery of objects and samples.

Currently there are no standardized methods for conservation, in the marine environment, of materials according to their nature (organic, metal, silica, etc.), although there have been some experiences both in laboratory (Björdal and Nilsson, 1998) as in the archaeological site (Stewart et al., 1994; Pournou et al., 1998; Gregory, 1999). The two most widely used techniques for long-term conservation of underwater archaeological sites in its natural environment are the preservation in situ and burial or "reburial" (MoSS Project, 2004). By in situ conservation, the archaeological site or a portion thereof is protected in the marine environment such is located (Bergstrand and Godfrey, 2007). At the burial, the archaeological site is excavated in its location, to be later buried in the same or another environment, either in one piece or dismantled. Both methods mainly used marine sediments or burial material as cover. These in turn are coated by layers composed by sandbags, concrete, or plastic geotextile (Oxley, 1996). However, the results that show a reduction in degradation depending on the nature of these materials are inconclusive, and even warn about the danger of extend these methods to different materials since the analysis have been mainly conducted on wood materials (Palma, 2005; Curci, 2006; Björdal and Nilsson, 2008), leaving out many of the archaeological materials of different nature.

The burial of the deposits as a measure of preservation is also criticized on the basis that the different methods proposed have been assessed inadequately and during excessively short periods of time. As an example, some authors have shown that microbial degradation is also present in protected wood buried in the sediment (Kim et al., 1996; Riess and Daniel, 1997; Björdal et al., 2000), although this method avoids the impact of boring organisms such as bivalve molluscs of the Teredinidae family or isopods from genus Limnoria. These studies showed that archaeological woods from marine sediments might have bacterial soft rot, and especially erosion forming bacteria, which are the predominant degrading microorganisms in the anaerobic environment nearby sediments. Little is known, therefore, on the relationship between the processes of colonization and degradation rate in relation to the depth of burial or sediment used for this purpose. 
There is another archaeological activity that may be adverse to the in situ conservation of underwater archaeological sites: the documentation. The different recording methods are adapted to the nature of archaeological data that purports to be documented, and there are as many methods as data types. In the marine environment is generally used photography and video (Green, 2004). But sometimes direct documentation is not possible. This circumstance occurs, for example, in shipwrecks in which the only materials on the sea bottom are cannons or anchors coated with thick concretions of biological and mineral origin. Although it is known the existence of marks and reliefs on these objects (as legend of the serial number, seals casting, etc.), this information remains hidden under the layer developed over the time and does not allow the documentary phase of the object. On the other hand it has been found that this concretion also acts as a protective layer against corrosion, considerably reducing the rate of corrosion of iron in seawater, and even keeping the metal in the passivity area of the Pourbaix diagram (Gregory, 1995; Gregory, 1998). Currently there are three alternatives to manage this issue: a) Renounce the historical knowledge of the shipwreck for the benefit of in situ conservation of the objects that compose it. In this case the paradoxical situation of preserving and protecting a historically unknown shipwreck occurs; b) remove objects for documentation. This option carries a high cost of conservation and the irreparable destruction of the archaeological context, not justifiable when the interest of the object is limited to its exclusive documentary feature; c) the de-concretion of the specific area with documentary interest. But the detachment of the concretion layer with archaeological purposes leads to the reactivation of metal corrosion process. In this paper we propose a non-destructive combined system of de-concretion, documentation and corrosion control as an alternative for a "sufficient" documentation in underwater archaeological context. This system is based in those described by MacLeod $(1995,2002)$ and Gregory (1995) and has been previously described in Bethencourt and Zambrano (2002) and Bethencourt et al. (2005). In order to re-position the iron in the passivity zone in the Pourbaix diagram (Pourbaix, 1963), we employed a coating that isolates the metal from the aggressive medium. This mechanism, named barrier effect, is based on the protection of the object through the electrical insulation produced by interposing a solid and continuous film between the metal and the corrosive medium.

In Riess and Daniel (1997) and MacLeod (1995) respectively, Gregory and MacLeod reported in situ treatments of iron fittings associated with historic shipwrecks and based in the cathodic protection. Periodic monitoring of corrosion potentials makes it possible to predict the rate at which a metal object deteriorates and to determine the most appropriate time to recover the object. The benefits of attaching sacrificial anodes to metal objects include an immediate decrease in corrosion rate and commencement of an active conservation treatment. A sacrificial anode typically comprises a metal such as zinc or an aluminum alloy electrically connected to the object to be protected, and with a higher activity in the scale of standard reduction potentials. Based in these experiences, in this work we proceeded to study and implement a pilot program of corrective measures based on the application for 9 months of cathodic protection on one of the cannons with the worst potential corrosion value.

Proposals on in situ conservation of the materials associated with an underwater archaeological site should be based inexorably in a detailed knowledge of the environment and the relationships between the UCH and the marine environment. The vulnerability assessment of UCH must take into account the nature of the site and the prevailing environmental conditions, and must be supplemented by studies as indicated by Rule 15 of the Convention. The variety of physicochemical underwater conditions allow shipwrecks to reach a certain "degree of stability" in many cases, making each of the archaeological sites forming the UCH an unique and unrepeatable example (Pearson, 1987). However, since the development in the 90 s of predictive models related to the processes of formation of underwater archaeological sites, the traditional concept that shipwrecks are comparable with time capsules chronologically frozen is quickly vanishing. Although theoretical and methodological developments are still necessary, it is now being assumed the great dynamism characteristic of this type of deposit, which represents a remarkable conceptual breakthrough. The processes acting on a shipwreck and determining its conservation state are very complex. The conservation itself is finally the result of the permanent interaction of the many agents involved acting either simultaneously or sequentially, and of the nature of the materials that compose the shipwreck. In order to protect a shipwreck, it is necessary to know the state of conservation of the materials and to identify the particular action of each agent to better understand their role in site conservation (Schiffer, 1983). Traditionally, the processes that affect a site are divided into two broad categories: natural and anthropogenic (Schiffer, 1987).

In the case of the underwater environment, anthropogenic action must be taken into account by means of the human-driven processes affecting the conservation of a shipwreck, such as environmental pollution, changes in coastal areas through dredging, port construction, urban construction, beach regenerations, and even fishing (Fig. 1a). Under current European legislation (The Treaty of Valletta, 1992) (European Convention on the Protection of the Archaeological Heritage (Revised), 1992), the potential effects of subsea development on the underwater cultural heritage (for example the placing of cables, pipelines, offshore wind mill parks), must be assessed in advance of any such developments. In this context, the European Commission's Seventh Framework Program sponsored the SASMAP project (2015) from 2012 to 2015. The aim of this important project, with 11 international partners, was to develop the techniques and methods to assess and protect the underwater cultural heritage in such at non-destructive and not intrusive manner as possible.

On the other hand, the natural processes that determine the formation and evolution of the underwater archaeological sites are of physical, chemical and biological nature, being in turn regulated by the action of the three main agents: water, sediment and living organisms (Gregory et al., 2009). To assess the impact of water, it is important to consider certain variables and physicochemical parameters, such as temperature, light, salinity, $\mathrm{pH}$, oxygen, and nutrients and the intensity and direction of currents and waves.

Taking into consideration the guidelines of the Convention, in this work we have studied many archaeological iron artefacts (mainly cannons and anchors) from two shipwrecks located in the vicinity of the Bay of Cadiz, covering different objectives according to the Rules discussed above:

Rule 4: a non-destructive technique has been employed in order to access to the documentary information present in the cannons without altering their condition, providing information about the origin of these wrecks and the different state of conservation at each site.

Rule 15: the main physical, chemical and biological factors that can impact on the shipwreck materials have been studied and correlated with the conservation status achieved at each site.

Rule 1: in situ conservation was improved through cathodic protection of large iron objects, following the experiences at Duart Point Wreck (Gregory, 1995), the Spanish shipwreck in Cala Spalmatore (Bartuli et al., 2008) and the HMVS Cerberus in Port Phillip Bay (MacLeod and Steyne, 2011).

Rule 25: the results obtained could be used to develop the decision making system of the Site Management Program, based on predictive models of permanence through the knowledge of materials and analysis of risk factors imposed by the marine environment.

\section{Materials and methods}

\subsection{Study sites}

We focused on two archaeological sites located near to the Bay of Cadiz, in the southwest coast of the Iberian Peninsula, known initially 


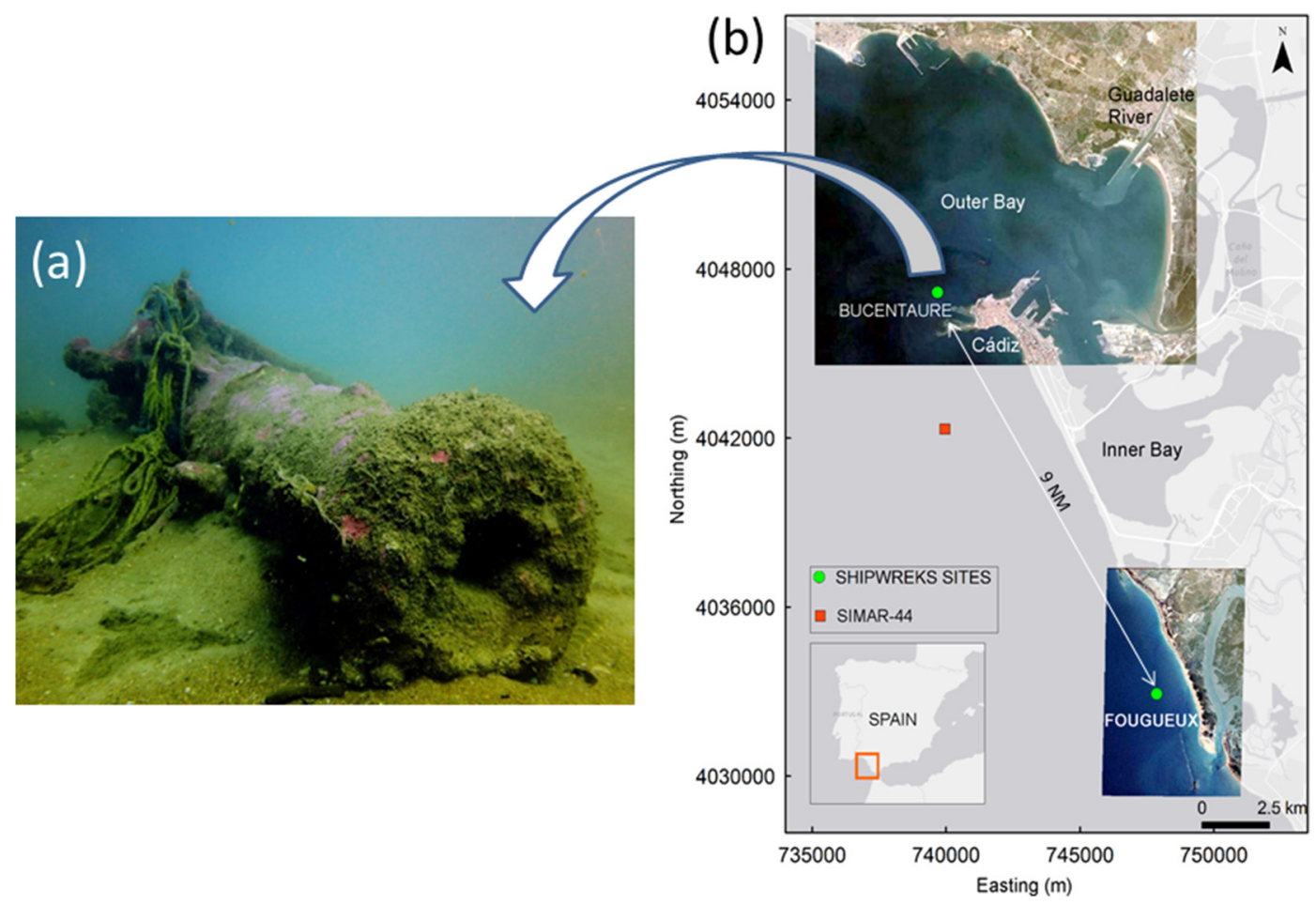

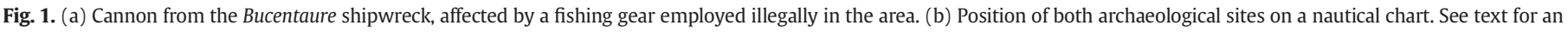
explanation of the symbols.

as the Chapitel Wreck and Las Morenas Wreck. These sites were chosen based on the different characteristics of the environment in which they are lying (bottom type, currents, depth, cycles of exposure-burial, associated biological community and degree of anthropic pressure). The choice of these sites had two additional advantages, ease of access to its location (proximity to the coast and the city of Cádiz, and their shallow depths) (Fig. 1b) and a similar chronology (both sites had cannons and anchors of the same typology). Subsequently, the Underwater Archaeology Centre of Andalusia identified these shipwrecks as Bucentaure and Fougueux ships respectively (García-Rivera and Alzaga-García, 2012), based on various documentary evidences, which include those presented in this paper.

\subsection{Environmental conditions}

This section summarizes the methodology applied to monitor and study the marine environmental conditions at Fougueux and Bucentaure sites.

\subsubsection{Sediment and morphodynamic characterization}

In order to characterize the sediment grain size, five sediment samples were manually collected by scuba divers at each shipwrecks site. Grain size analysis was performed through dry sieving method. Subsequently, statistics of particle size distributions were computed with the Folk and Ward method using the GRADISTAT software developed by Blott and Pye (2001). The sediment mobility and the geomorphological changes in the shipwrecks sites were evaluated by an accretionerosion model derived from time lapsed bathymetric surveys conducted by using Multiand Single Beam Echo sounder (MBES and SBES) (Quinn and Boland, 2010) and by bed forms study on the sites. MBES were conducted on 13.11.2013 and 23.04.2014 at Bucentaure site with a $200 \mathrm{kHz}$ Reson Seabat 8124 ( $1.5^{\circ}$ beam width, $0.01 \mathrm{~m}$ vertical resolution and $40 \mathrm{~Hz}$ sample rate). Positional data were acquired using a Leica 1200 RTK-DGPS. Tidal- and wave- corrections were derived from RTK-DGPS data and sound velocity corrections from a Reson SVP70. SBES were conducted on 28.11.2011 and 21.05.2013 at Fougueux site using a
$235 \mathrm{kHz}$ Ohmex Sonarmite v3.0 (sample rate $1 \mathrm{~Hz}$ and theoretical vertical resolution $0.05 \mathrm{~m}$ ). Positional data were provided by a Leica 1200 RTK-DGPS. SBES data were tide- and wave-corrected using RTK-DGPS data and sound velocity corrections from an IDRONAUT 305-CTD. The difference models for the accretion-erosion assessment of the wreck sites were constructed in ArcGIS v10.1, using a kriging interpolator and ordinary prediction.

\subsubsection{Hydrodynamic characterization}

Time series of wave parameters and current velocity were acquired at Fougueux and Bucentaure sites, during different field campaigns conducted in 2013. From 30.07.2013 to 09.09.2013 (40-day series record) a bottom mounted Acoustic Doppler Current Profiler (ADCP) located at each shipwreck site was used to obtain the current velocity profile in the whole water column. The two ADCP (AWAK $600 \mathrm{kH}$ Nortek SA) operate at $1 \mathrm{~Hz}$ sampling rate and computed 1-minute current velocity average for each depth cell $(0.5 \mathrm{~m}$ size $)$ each 10 -minutes interval. An Electromagnetic Current-meter (EM) COMPACT-EM model (ALEC ELECTRONICS CO) along with a pressure sensor (PS) AQUAlogger ${ }^{\circledR}$ 210TY model (AQUATEC) was moored $0.75 \mathrm{~cm}$ above seabed at Fougueux (from 02.06.2013 to 27.06.2013) and Bucentaure (from 27.04.2013 to 02.05.2013) site. The EM and PS measurements were taken hourly in burst of $1200 \mathrm{~s}$ with a sampling frequency of $1 \mathrm{~Hz}$. EM current-meter was able to characterize the near bottom current and wave orbital velocities. Then, the acquired data (EM and PS) were subjected to statistical and harmonic analysis to facilitate the characterization of wave and current conditions (Thomson and Emery, 2014).

On the other hand the wave climate regime at Fougueux and Bucentaure sites was modelled by propagating a historical 44-yearlong hourly wave time series (SIMAR-44) (Fig. 1b) to both shipwreck locations using the Oluca-SP model (Grupo de Ingeniería Oceanográfica y de Costas (GIOC), 2001). SIMAR-44 data provided the offshore wave spectral characteristics (significant wave height, $\mathrm{Hs}_{0}$, peak period, $\mathrm{Tp}_{0}$, wave direction, $\theta_{0}$, and sea water level (SWL)). These deep-water spectral waves were propagated on each site, and the local sea state parameters $\left(\mathrm{Hs}_{\mathrm{i}}, \mathrm{Tp}_{\mathrm{i}}, \theta_{\mathrm{i}}\right)$ were obtained for each of the 385,704 hourly offshore 
sea states. After the reconstruction of local wave time series in both sites, the scalar wave climate regime of significant wave height (Hs) and bottom orbital velocity (Uw) were calculated.

\subsubsection{Geochemical characterization}

In order to characterize the chemical properties of the surface sediments, sediment cores were sampled at Fougueux and Bucentaure sites. Three sediment cores with $60 \mathrm{~cm}$ length and $5.7 \mathrm{~cm}$ diameter were manually collected by scuba divers. $\mathrm{pH}$, oxidation-reduction potential (ORP) and total organic carbon (TOC) were measured on a $3 \mathrm{~cm}$ interval in order to characterize the above depth dependence of the parameters. pH and ORP were measured using HANNA 1053B pH and HANNA HI3131B ORP instruments respectively, whereas TOC was measured using the titration method (El-Rayis, 1985).

\subsubsection{Hydrochemical characterization}

Through different field experiments extending from 2011 to 2014, multiparametric probe profiles (Hidronaut 305 probe) were monthly acquired in order to evaluate seasonal variation of seawater characteristics. Variables as salinity $\mathrm{S}(\%)$, temperature $\mathrm{T}\left({ }^{\circ} \mathrm{C}\right), \mathrm{pH}$, redox potential $(\mathrm{mV})$ and dissolved oxygen $(\mathrm{ppm})$ were measured on a $10 \mathrm{~cm}$ depth interval thorough the water column.

\subsubsection{Biological characterization}

The characterization of the biological community in Fougueux and Bucentaure sites was carried out through two different studies. First a quantitative analysis of sessile community in natural rocky bottom was performed. Video transect sampling was carried out during cold and warm season. Three random replicated belt transects of 50 $\times 300 \mathrm{~cm}$ by site and season were carried out. A digital video camera (Sony HDR XR-550) in an underwater housing was used to obtain video images. The camera was held $\sim 40 \mathrm{~cm}$ above the seabed and the operators moved at a constant speed along each transect. The number of each sessile species was counted along transect lines. On the other hand, a quantitative analysis of sessile community on artificial substrate was performed. Panels of $20 \times 30 \mathrm{~cm}$ and different materials (copper, brass, cast, iron, pine and oak) were seated on sandy seabed, and on rocky seabed in both studied sites (Fig. 2). Six panels of each material were used. Photoquadrat images of the panels were collected periodically by SCUBA diving using a Canon PowerShot S100 digital camera. The photoquadrat apparatus was constructed from PVC and attached to the underwater housing camera following other studies (Preskitt et al., 2004; Van Rein et al., 2011). Abundance estimations were made calculating the percentage cover by 100 fixed point-interception (Van Rein et al., 2011; Masi et al., 2009; Van Rein et al., 2012) using image analysis software NIS-Elements Advanced Research V.4.0 (Nikon NIS-
Elements Advanced Research, 2014). In the two studied substrates, specimens were identified to the lowest taxonomic level of resolution possible, in most cases to species level. Additionally, to assist the identification of the species, samples were collected for the subsequent analysis in the laboratory. These species were preserved in ethanol 70\%. The data were organized in species/sample abundance matrix. The multivariate analysis was based on the Bray-Curtis similarity matrix of square root-transformed data (Bray and Curtis, 1957). The dissimilarities among samples were represented by non-metric multidimensional scaling ordinations (nMDS), (Clarke, 1993). These analyses of the abundance and composition of the species were performed using PRIMER v6.1.11 (Clarke and Gorley, 2006).

\subsection{Archaeometallurgy analysis}

\subsubsection{Combined system for archaeological record and in situ corrosion control}

The de-concretion was carried out in the selected area (trunnion, breech, cascabel, etc.) with hand tools and mechanical pneumatic tools traditionally used in conservation laboratories, following our patented methodology (Bethencourt and Zambrano, 2002; Bethencourt et al., 2005). This methodology limits the action of the elimination of concretion to very specific areas with documentary interest, and preserves the integrity of the object. In this way it was possible to identify the nature and origin of the cannons registering, for example, the numbers incised on the breech without removing the entire concretions whose knowledge allowed us a better understanding the history of these objects.

Once the object is documented, and in order to re-position the iron in the passivity zone in the Pourbaix diagram, a coating isolating the metal from aggressive medium is used. This coat, based in a two components epoxy resin (Eporai A and Eporai B), prevents the oxidizing environmental agents access to the metal surface, inhibiting thus the cathodic reaction of the corrosion process. The coat is miscible in water and is used in the shipbuilding industry for application in wet or submerged surfaces.

In both shipwrecks some of these cannons and anchors were selected as witnesses, in order to establish their current conservation status and evolution if staying at the sea bottom. At this stage, partial deconcretion tasks for in situ $\mathrm{pH}$ and corrosion potential $\left(\mathrm{E}_{\text {corr }}\right)$ measurements were made following the proposed method. The prediction was made by applying the linear relationship between the logarithm of the corrosion rate $\left(\mathrm{V}_{\text {corr }}, \mathrm{mm} / \mathrm{year}\right)$ and the potential of corrosion of iron in seawater ( $E_{\text {corr }}$, volts) (Gregory, 1998; MacLeod, 1995):

$$
\log \left(\mathrm{V}_{\text {corr }}\right)=\mathrm{M} \cdot \mathrm{E}_{\text {corr }}+\mathrm{C}
$$
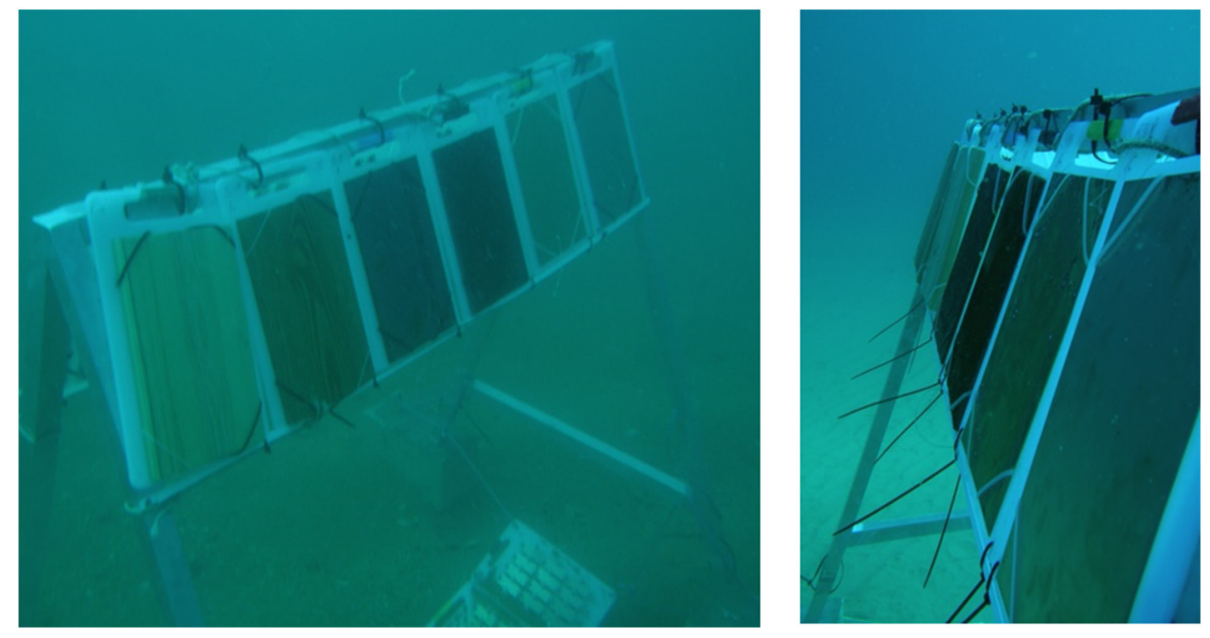

Fig. 2. Frames supporting copper, brass, cast, iron, pine and oak panels in the Bucentaure site (left) and in the Fougueux site (right). 
where $\mathrm{M}$ and $\mathrm{C}$ are parameters of the linear fit. When the oceanographic conditions of the sites are very similar, the corrosion equations have very close similar slope or $\mathrm{M}$ value but the intercept value, $\mathrm{C}$, is quite sensitive to the water depth and water movement (MacLeod, 2013). With different macro-conditions (i.e. different bodies of seawater) it was found that the slope $\mathrm{M}$ of the equation had different values that where sensitive to the temperature and salinity of the wreck site (MacLeod, 2013). The amount of dissolved oxygen in seawater is interrelated with these variables, which also affect the diffusion rates as well as the kinetics of electron transfer and the thickness of the marine concretion.

A total of four measurements per cannon or anchor, distributed throughout a year, were performed, establishing the average value of $\mathrm{E}_{\mathrm{corr}}$ for each artefact. The maximum error between these four measures of the same artefact in any case did not exceed $\pm 25 \mathrm{mV}$, justifying the use of the average. Similarly, a pH measurement inside the concretion was performed immediately after drilling with pneumatic tool, which also allowed measuring the thickness of the graphitic area. The corrosion rate was estimated as the ratio of the thickness of the graphitic layer in the concretion measured with a caliper by the number of years of immersion of the object (MacLeod, 1995). The thickness of the concretion layer was measured by a caliper after making a hole therein by using a pneumatic drill coupled to a compressed air cylinder as described previously.

Finally, and only for the Bucentaure shipwreck, we proceeded to study and implement a pilot program of corrective measures based on the application for 9 months of cathodic protection on one of the cannons with the worst potential corrosion value, following the methodology proposed by Gregory (1995) and MacLeod (1995) and the experiences of Gregory (1995), Bartuli et al. (2008) or MacLeod and Steyne (2011). In this work a zinc anode was employed. After the electrical connection with a copper wire, electrons flow occurs through the cable from the corroding anode to the cathode (in this case the cannon) which is protected. The corrosion cell is completed by the surrounding seawater, which closes the circuit.

The anode was electrically connected to the cannon through a drilling made through the concretion and the graphitic zone until reaching the remaining metal surface. Finally, this palliative proposal was monitored. After the evaluation period, the sacrificial anode was extracted again, reintegrating the cannon to its original thermodynamic state.

\subsubsection{Metallurgical examination}

The materials studied in the laboratory were rests of the eliminated concretions for documentary records purposes, made on the cannons and anchors, and a cannon ball extracted for electrochemical treatment at low current density $\left(50 \mu \mathrm{A} / \mathrm{cm}^{2}\right)$ with the object of optimizing a methodology for the conservation of archaeological iron objects (Bethencourt et al., 2004), and a sample of a 12-prd cannon extracted by the Underwater Archaeology Centre of Andalusia from the Bucentaure shipwreck.

For the analysis of the components present in the samples, the X-ray powder diffraction (XRD) spectra was used; these were recorded by means of a Philips diffractometer with a graphite monochromator $(\mathrm{CuK} \alpha)$, at $40 \mathrm{kV}$ and $40 \mathrm{~mA}$. The step-scan data were collected over the $2 \theta$ angular range $3-80^{\circ}$, using a step size of 0.015 and a counting time of $2 \mathrm{~s}$ per step. For the quantitative analysis of the different components of the XRD spectra, the Rietveld method was employed, and for the treatment of the data obtained by this method, the original Fullprof program (Mumme et al., 1996) was applied. The fit between the experimental and calculated profiles was expressed in terms of the standard index of goodness ( $\mathrm{G}$ of F), defined by Young et al. (1982). The chemical composition of the metallic nucleus of the object was determined using a Spectrolab Jr model Spark Spectrometer, from Spectro. The microstructural characterization was performed with a Jeol 820-SM model scanning electron microscope, fitted with a LINK AN-10000 model energy dispersive spectrometer (EDS).

For the metallurgical and microscope observations, the sample of the 12-prd cannon was ground in successive carbide paper grits $(220,400$, 600 and $1200 \mathrm{SiC}$ ) and micropolished with diamond paste over a felt wheel in order to remove superficial defects such as marks and scratches from the last ground material. After the micropolishing process, the sample was etched with nital $2 \%$ until the sample turned into dull grey; it was then washed with distilled water and dried in a hot air stream. This procedure was repeated until the microstructure was clearly revealed. Optical observations were carried out using an inverted metallographic microscope (Leica DM IRM) controlled by proprietary image software.

\section{Results}

\subsection{Wreck sites}

The Bucentaure represents a scattered shipwreck where a total of 22 iron cannons, an anchor and other metallic artefacts are preserved (Fig. 3). The site is located in the outer Bay of Cadiz, on the mixed rocky-sandy seabed at $12 \mathrm{~m}$ depth. Meanwhile, in the S.M.I. Fougueux site, an important portion of the hull structure is preserved, along with 32 cannons and an anchor (Fig. 4). Fougueux is seated on a sandy
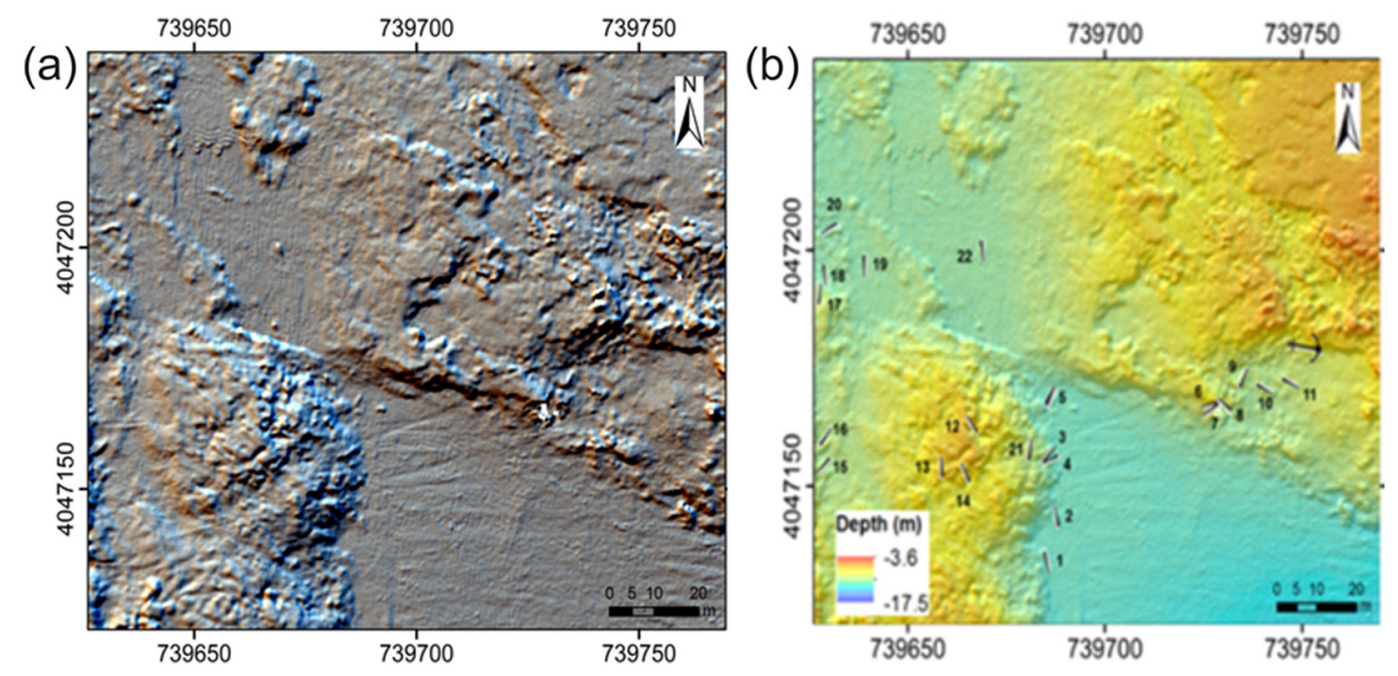

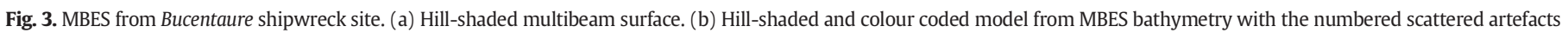
analyzed during the in situ corrosion study. (For interpretation of the references to colour in this figure legend, the reader is referred to the web version of this article.) 

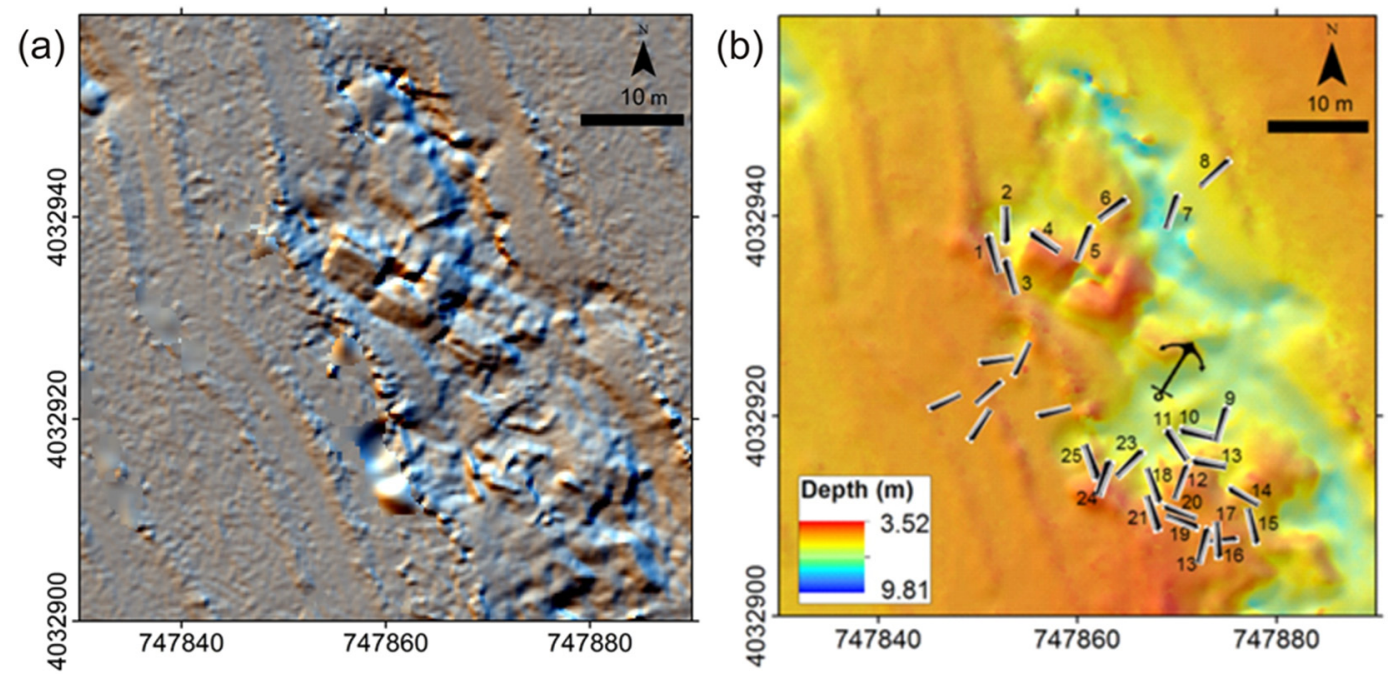

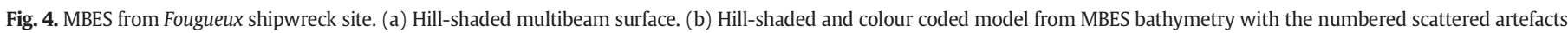
analyzed during the in situ corrosion study. (For interpretation of the references to colour in this figure legend, the reader is referred to the web version of this article.)

seabed at $7 \mathrm{~m}$ depth next to a little rock shoal. Located in front of the Sancti Petri sand spit, it is exposed to west and southwest wind waves. It is the only one of the two shipwrecks that preserves remains of the wooden hull buried under fine sand.

\subsection{Environmental and biological conditions}

The grain size analysis shows differences between sampled stations; while at Bucentaure sediments can be classified as moderately sorted coarse sand $\left(D_{50}=1.095 \mathrm{~mm}\right)$, the Fougueux site sediment is categorized as well sorted fine sand $\left(D_{50}=0.177 \mathrm{~mm}\right)$. The coarser grain size at Bucentaure hampers the sediment transport in suspension mode, whereas at Fougueux size the smaller grain size is likely transported in suspension mode. In addition, well-sorted sediments are present in the Fougueux, correlated with the higher energy conditions in this area. According to the Shield's parameter that indicates the threshold of sediment mobility, bed shear stress should be larger than $0.55 \mathrm{Nm}^{-2}$ to initiate the sediment motion at Bucentaure site, whereas at Fougueux bed shear stress values of $0.15 \mathrm{Nm}^{-2}$ are enough for initiate the sediment motion.

Erosion-accretion models were constructed from the tide- and wave- corrected MBES and SBES data for Bucentaure and Fougueux sites respectively (Fig. 5). Bucentaure site (Fig. 5a), net erosion takes place in both toes of shelf rocky shoal (1) and (2), reaching up to $0.30 \mathrm{~m}$. Net erosion is also found in other area (3) but with lower values $(0.2 \mathrm{~m})$. In contrast, net accretion $(0.3 \mathrm{~m})$ was measured in the other side of the shelf rocky channel (4). At Fougueux site (Fig. 5b) greater changes, up to 0.6-0.7 m, were measured at the hull structure and rocky shoal (5). Outside the hull remains and rocky shoal net deposition is recorded with mean values of $0.05-0.20 \mathrm{~m}$., with a maximum net erosion of $0.6 \mathrm{~m}$ in shore of the shipwreck (6).

Rose diagram of the depth-averaged current velocity (Fig. 6) shows that larger current velocities were registered at Fougueux site. Currents are mostly parallel to shore line in both studied sites, NNW-SSE at Fougueux and WSW-E at Bucentaure site, with maximum values of $0.50 \mathrm{~m} \mathrm{~s}^{-1}$ (Fig. 6a) and $0.35 \mathrm{~m} \mathrm{~s}^{-1}$ (Fig. 6b) respectively. The current velocity time series were analyzed using harmonic and spectral analysis. The velocity amplitude of the main semidiurnal tidal harmonic, M2, was close to $0.20 \mathrm{~m} \mathrm{~s}^{-1}$ at Bucentaure and $0.10 \mathrm{~m} \mathrm{~s}^{-1}$ at Fougueux.

The lower panel shows the importance of waves. Even relatively small waves present important orbital velocities at Fougueux site. In addition, for similar values of significant wave height (Fig. 6c) the orbital velocity is larger at Fougueux than at Bucentaure (Fig. 6d) due to the shallower depth. Consequently, the bed shear stress induced by waves is markedly larger in Fougueux site, where it can promote higher rates of sediment transport and remobilization.

The Fig. 7 displays the scalar wave climate at Fougueux and Bucentaure sites obtained from the wave propagation model. The lognormal distribution of significant wave height (Hs) (Fig. 7a) shows that at both locations the significant wave height (Hs) is $<1 \mathrm{~m}$ the $50 \%$ of the time during an average year. Fougueux showed higher values of Hs 78\% of time during an average year. In addition, at Fougueux during extreme storms $(\mathrm{Hs}>3.85)$ waves break promoting higher energy events. Bottom orbital velocities are always larger at Fougueux than at Bucentaure (Fig. $7 \mathrm{~b}$ ) with values of $0.5 \mathrm{~m} \mathrm{~s}^{-1}$ and $0.25 \mathrm{~m} \mathrm{~s}^{-1}$ (50\% probability of nonexceedance), and $1.1 \mathrm{~m} \mathrm{~s}^{-1}$ and $0.6 \mathrm{~m} \mathrm{~s}^{-1}$ (90\% probability of nonexceedance) at Fougueux and Bucentaure, respectively.

Geochemical differences were found at Fougueux and Bucentaure sediment surface layer (Fig. 8). Fig. 8a shows pH values quite similar at both locations, $\mathrm{pH}$ values mostly ranging from 7.4 to 7.8 slightly more acid than $\mathrm{pH}$ values in the water column ( 8.2).

Despite the limited depth reached in the cores collected at Bucentaure, differences in ORP (Fig. 8b) were observed even in the first $15 \mathrm{~cm}$ of sediment layer. Thus, ORP reached $225 \mathrm{mV}$ mean value in Bucentaure site, whereas at Fougueux site $130 \mathrm{mV}$ was measured. As ORP may be considered as a proxy of oxygen concentration, data revealed lower oxygen concentration in sediments at Fougueux site. Negative values of ORP were measured deeper $15 \mathrm{~cm}$ at Fougueux site, which can be related to the existence of anoxic conditions. The TOC (Fig. 8c) shows small concentrations at two sites and quite constant in depth. Low values of TOC $(0.145 \%)$ were registered at Fougueux site, whereas slightly higher values $(0.155 \%)$ were measured at Bucentaure site.

The seasonal cycle of the temperature and salinity after monthly average of the data recorded from 2011 to 2014 at Fougueux and Bucentaure locations have been plotted in Fig. 9. The Fig. 9a represents the annual cycle of temperature at Fougueux and it shows values from $14{ }^{\circ} \mathrm{C}$ recorded on March up to $23.7^{\circ} \mathrm{C}$ on September. The vertical orientation of the isotherms reveals a well-mixed water column during all seasons. This is not surprising given the shallowness of the site. At Bucentaure site (Fig. 9b) the range and pattern of variation are similar to those found in Fougueux site, with changes of $13^{\circ} \mathrm{C}$ to $23^{\circ} \mathrm{C}$ from February to September. Well-mixed waters were recorded from January to June. However, from July to December some thermal stratification appears in the near bed layer. As result a maximum vertical gradient of temperature of $4{ }^{\circ} \mathrm{C}$ was reached during August and September. In this stratified period the surface temperature changed from $19{ }^{\circ} \mathrm{C}$ to $24{ }^{\circ} \mathrm{C}$, whereas at the near bed layer remained below $20{ }^{\circ} \mathrm{C}$ most of the time. 

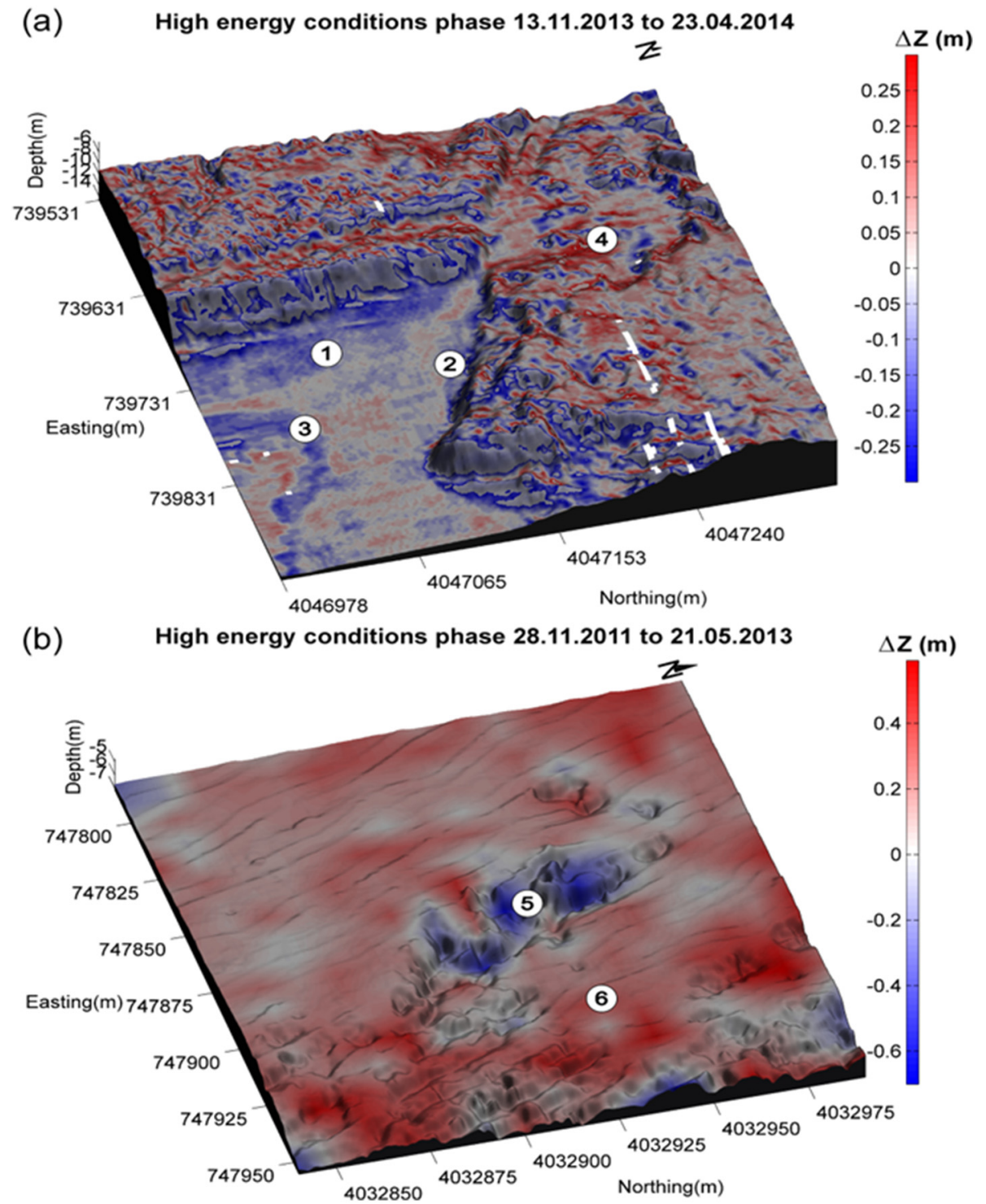

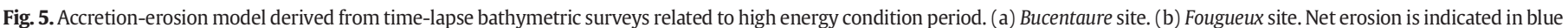

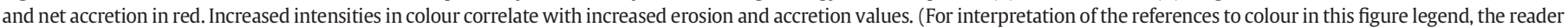
is referred to the web version of this article.)

Fig. 9c depicts the seasonal variation of salinity at Fougueux site, the vertical isohalines indicates no stratification, with the exception of a very superficial stratification that does not penetrate beyond $1 \mathrm{~m}$ depth. Seasonal values range between 35.5 psu in April and 36.5 psu in September. Fig. 9d illustrates the seasonal variation at Bucentaure site. The graph displays a surface stratification between January and April. The decrease in the surface salinity ( $35 \mathrm{psu}$ ) penetrates down to $7 \mathrm{~m}$ deep and is possibly associated to the discharge of the neighboring Guadalete River. From July to December the near bed layer is characterized by lower salinities (below 36 psu), somehow compensating the thermal stratification.

Regarding with biological community characterization at Fougueux and Bucentaure sites showed variations in the hard substrate sessile community, as well as in artificial substrate.

Fig. 10a shows the dissimilarities among samples that were represented by nMDS of the sessile community developed on artificial substrate in Fougueux and Bucentaure sites for every month sampled. The dissimilarities in community evolution can be noted only after two months of exposure; differences are markedly greater after 15 month of exposure. After two months algae were the largest group to determine the differences between sites. However, after 15 month of exposure, molluscs, bryozoans, annelids and barnacles also contributed to differentiate the community between both sites. Algae, the mollusc Teredo navalis and the bryozoan Escharoides coccinea were more abundant in Fougueux site, whereas serpulid polychaetes as Filograna implexa, Spirobranchus triqueter and barnacle Balanus sp. were more profuse in Bucentaure site.

The nMDS (Fig. 10b) shows differences between biological communities developed on natural rocky substrate in the studied zones. It should be noted that sessile community in Bucentaure site remained unchanged, unlike seasonal changes observed in Fougueux site. In the latter, the main species that characterized the community were algae: Cystosseira sp., Halopithys incurva, Laurencia obtusa or Plocamium cartilagineum. In Bucentaure algae were found, although also contributed to differentiate from Fougueux some species of sponges (Aplysina aerophoba, Dyctionella sp., or Dysidea incrustans), squirts (Ecteinascidia turbinata) or polychaetes (Filograna implexa). The latter species formed $\mathrm{CaCO}_{3}$ concretions. 
(a)

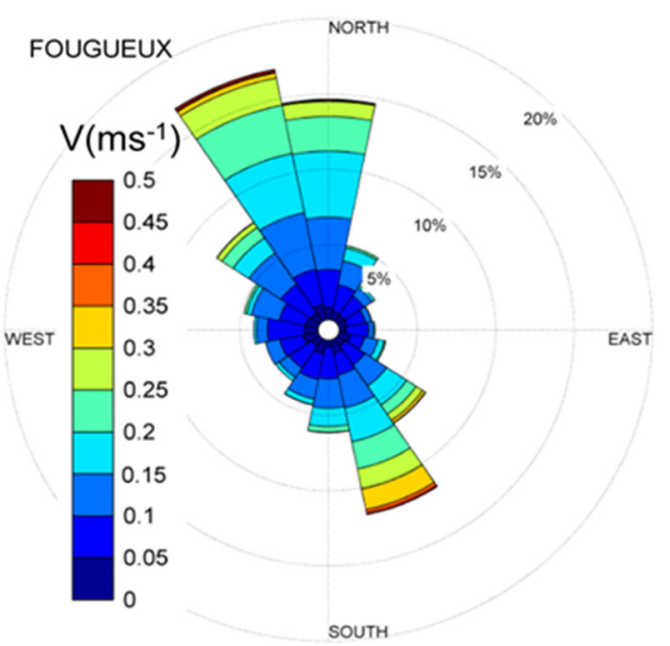

(c)
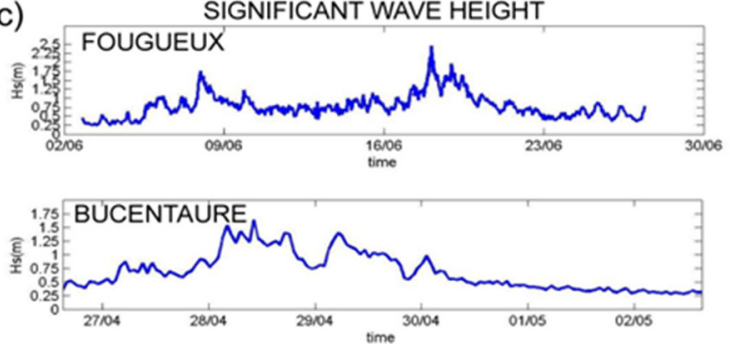

(b)

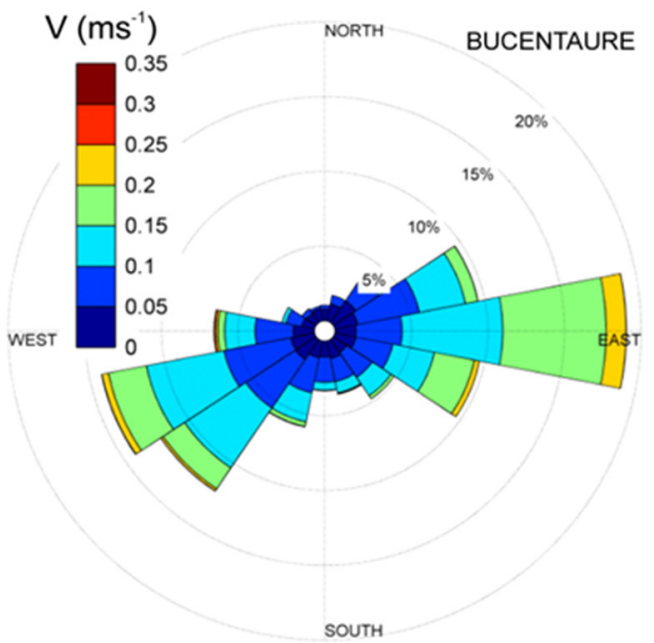

(d)
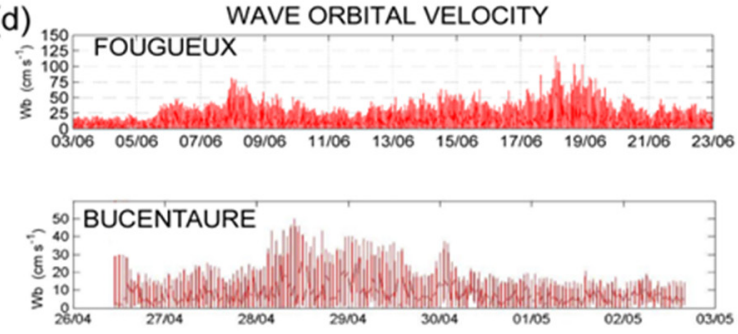

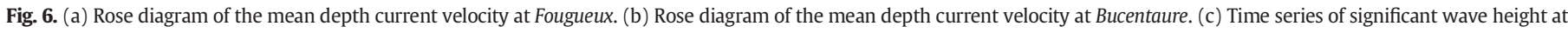
Fougueux and Bucentaure sites. (d) Time series of near bottom orbital velocity at Fougueux and Bucentaure sites.

\subsection{Archaeometallurgy studies}

The metallographic analysis made on the cannon extracted from the Bucentaure shipwreck showed that it was manufactured through a casting process with grey iron, showing the general appearance characteristic of grey cast iron with a ferritic - perlitic matrix and large graphite flakes of Type $C$ with random orientation, which is usually found in hypereutectic irons. In the absence of more samples, it was estimated that all cannons in both shipwrecks must have a similar microstructure, based in grey cast iron.

Examination of the concretion layers removed for documentary record purposes made on the cast iron cannons showed an outer graphite layer with cementite $\left(\mathrm{Fe}_{3} \mathrm{C}\right)$ appearing in the less corroded areas. As the residual metal was approached pearlite and ferrite phases were found. The graphite forms a three dimensional network. However, anchors are made of wrought iron that consists mainly of ferrite with silicate inclusions, and in this case the corroded metal does not retain the shape of the object and the corrosion products are soft and non-adherent.

Table 1 shows the results of the quantitative phase analysis by XRD and the associated standard deviations for the sample of the corroded surface on the cannon ball.

In akaganeite $\left(\mathrm{Fe}^{3+} \mathrm{O}(\mathrm{OH})\left(\mathrm{Cl}_{0.19}\right)\right)$ chloride ions are necessary for its formation and stabilization. The presence of this mineral was also corroborated by means of Scanning Electron Microscopy in the typical shape of the tip of a cigar described in Cornell and Giovanoli (1990). Also the chemical analysis by means of the corresponding energydispersive X-Ray spectroscopy spectrum showed the presence of $\mathrm{Cl}^{-}$ ions in its composition.

Fig. 11 shows a section of the cannon ball corrosion layer at the transition between corrosion products and uncorroded metal (ferrite and perlite). Corrosion has occurred specially at the graphite-metal interface, as a result of which corrosion has penetrated along the path of the graphite flakes. The main phase is akaganeite, and is in contact with the metal.
The method proposed in section 2.2.1 allowed us to access documentary information without compromising the level of protection offered by these layers. So, two objectives were achieved: The documentation of the remains and the study of corrosion processes. On the one hand provided a valuable documentary tool based on access to stamps and casting marks (Fig. 12). The removal of the concretion in areas of documentary interest showed that this layer had inhibited its corrosion to a remarkable degree and in some cannons surface markings were still clearly visible.

On the other hand, using the proposed technique it was possible to obtain information on these layers in various artefacts localized in both sites, and to relate some differences in their state of conservation with the situation of archaeological object on the seabed (sandy-rocky substrate, degree of burial, etc.). Despite the spatial proximity of the sites and their identical chronology, there are differences in the state of conservation of both shipwrecks. It has been observed that biological concretions associated with the Fougueux cannons are different to those from Bucentaure: in contrast to the calcareous concretion layer in Fougueux cannons, uniform and fine (about $5 \mathrm{~mm}$ of average thickness), the cannons from the Bucentaure have a concretion layer thicker, up to $30 \mathrm{~mm}$ thick. Furthermore, the $\mathrm{pH}$ inside the concretions and the corrosion potential $\left(\mathrm{E}_{\mathrm{corr}}\right)$ associated with each of the studied cannons and anchors were measured. All these data are shown in Table 2.

With these data the equation proposed by MacLeod (Eq. (1)) reads as follows for each of the sites:

Bucentaure: $\log \left(\mathrm{V}_{\text {corr }}\right)=4.203 \cdot \mathrm{E}_{\text {corr }}+1.3166\left(\mathrm{R}^{2}=0.9243\right)$

Fougueux : $\log \left(\mathrm{V}_{\text {corr }}\right)=1.786 \cdot \mathrm{E}_{\text {corr }}+0.2058\left(\mathrm{R}^{2}=0.843\right)$

The variability of the extent of corrosion at each site is shown in Fig. 13. 

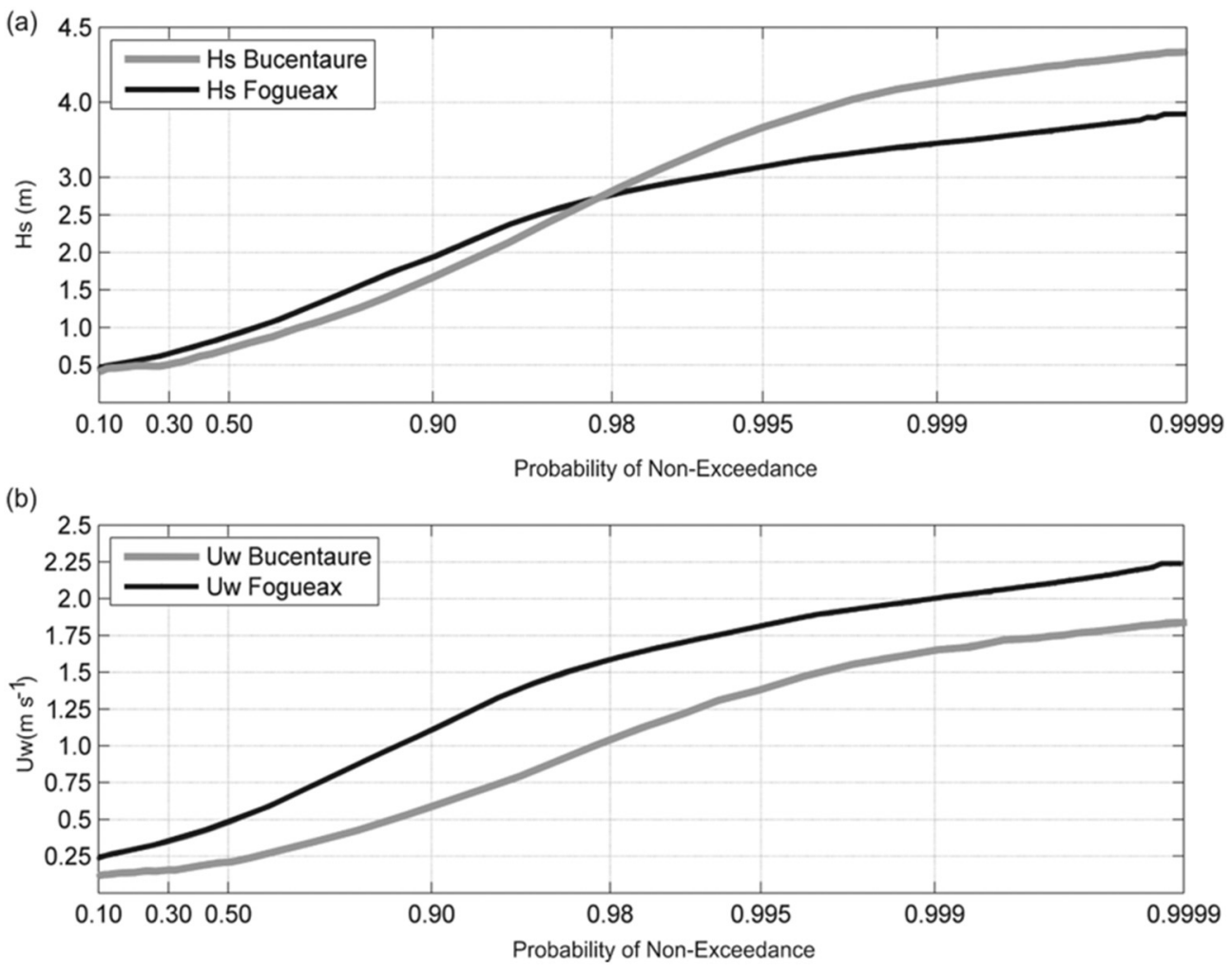

Fig. 7. Scalar wave climate. (a) Log-normal distribution of significant wave height. (b) Log-normal distribution of near bottom orbital velocity calculated using linear theory.

So, while the loss of material due to corrosion in Fougueux cannons ranges from 0.180 to $0.246 \mathrm{~mm}$ per year, in the Bucentaure is from 0.073 to $0.126 \mathrm{~mm}$. Overall, it seems clear that the cannons located at the Fougueux have been subjected to greater corrosive influences during the two centuries of exposure. These conditions must be related to the physical, chemical and/or biological parameters surrounding each shipwreck, and their temporal variations.

In the Fougueux case, the general plan of the site (Fig. 4) shows that cannons no. 4, 5, 6, 9, 10, 12, 21, 22, 24 and 25, with high corrosion rates (dark grey overlay in Table 2), are located near the edges of the reef, (a)

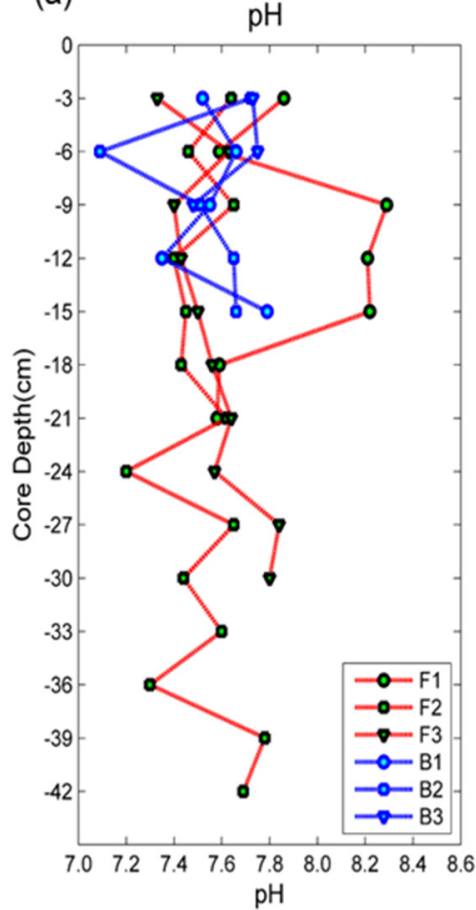

(b)

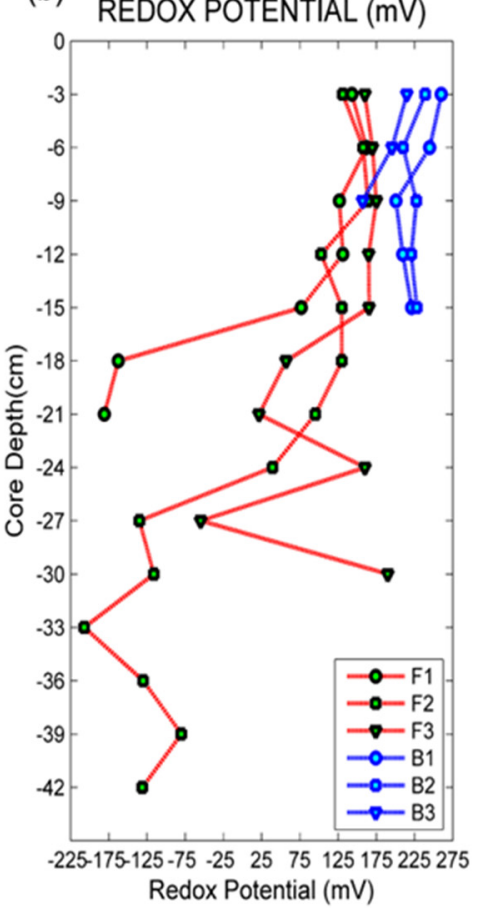

(c)

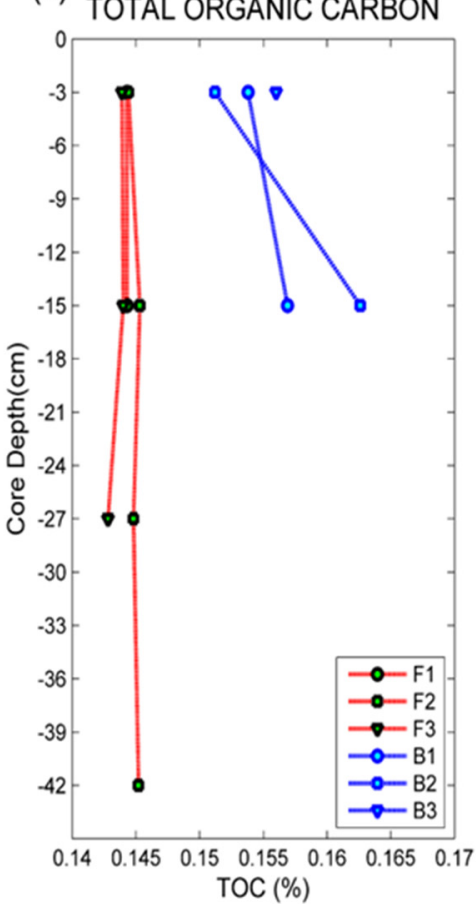

Fig. 8. Geochemical characteristics of the surface sediment layer at Fougueux and Bucentaure locations. (a) pH profiles. (b) ORP profiles. (c) TOC profiles. 

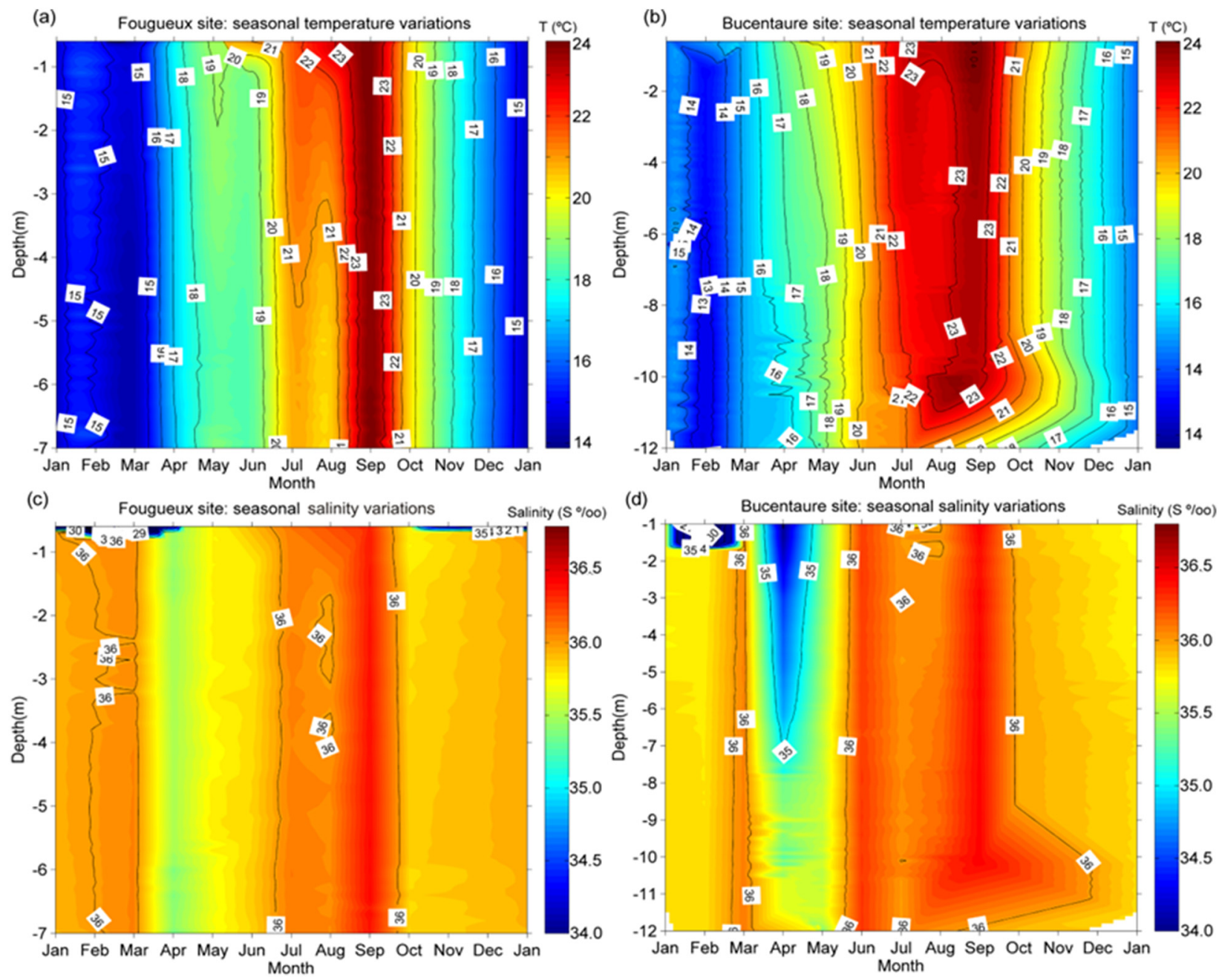

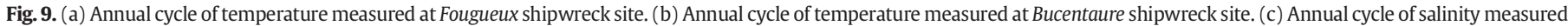
at Fougueux shipwreck site. (d) Annual cycle of salinity measured at Bucentaure shipwreck site.

where the interaction of oscillatory flow and the steady flow with the morphology of the wreck and the rocky reef produces the resuspension of the sediments accentuating the mechanical abrasion. This zone coincides with the maximum erosion area according to the time-lapse bathymetric survey (Fig. 5b). Rather opposite, cannons located on the shallower area on the rocky reef (i.e. no. 14, 16, 17, 18 and 19, 20) are those having a lower corrosion rate.
Thus, Fougueux cannons can be grouped into two groups according to their position in the field, resulting in two new expressions instead of one (expression $2 \mathrm{~b}$ ), resolved as follows for each area:

Cannons near the edges of the reef marked as dark grey in Table 2:

$\log \left(\mathrm{V}_{\text {corr }}\right)=0.9176 \cdot \mathrm{E}_{\text {corr }}-0.19(\mathrm{R} 2=0.9561)$

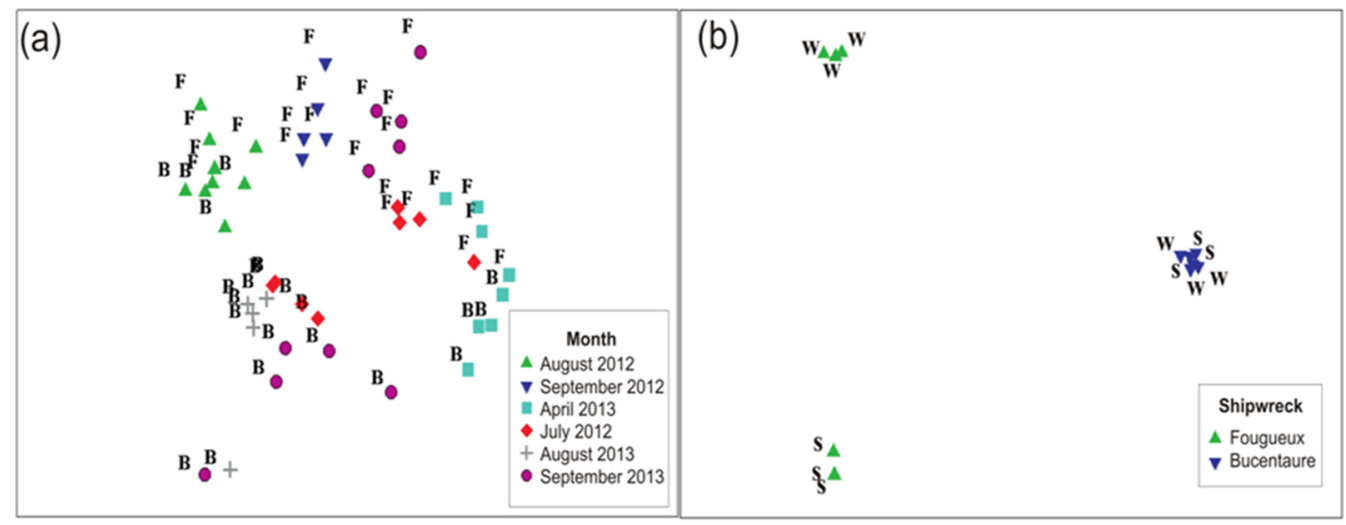

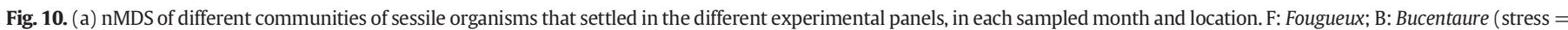
0.13). (b) Graphical Representation by nMDS (stress $=0.01$ ) of the sessile community sampled by video transects during cold season (W) and warm season (S). 
Table 1

Mineral phases of the corroded surface.

\begin{tabular}{lllll}
\hline Bragg reflections & Mineral name & Compound & wt\% & S.D. \\
\hline Phase 1 & Quartz & $\mathrm{SiO}_{2}$ & 45.30 & 0.36 \\
Phase 2 & Akaganeite & $\mathrm{Fe}^{3+} \mathrm{O}(\mathrm{OH})\left(\mathrm{Cl}_{0.19}\right)$ & 20.73 & 0.23 \\
Phase 3 & Magnetite & $\mathrm{Fe}_{2}^{3+} \mathrm{Fe}^{2+} \mathrm{O}_{4}$ & 1.85 & 0.46 \\
Phase 4 & Plagioclase (albite) & $\mathrm{NaAlSi}_{3} \mathrm{O}_{8}$ & 18.46 & 0.29 \\
Phase 5 & Siderite & $\mathrm{Fe}^{2+} \mathrm{CO}_{3}$ & 13.66 & 0.22 \\
\hline
\end{tabular}

Cannons on the rocky reef marked as light grey in Table 2:

$\log \left(\mathrm{V}_{\text {corr }}\right)=0.6002 \cdot \mathrm{E}_{\text {corr }}-0.4158(\mathrm{R} 2=0.9541)$

Once recognized the state of conservation of the cannons, we decided to use a cathodic protection system in the cannon no. 6 from Bucentaure.

In Table 3 the evolution of the corrosion potential on cannon No. 6 from the Bucentaure is shown, before and after incorporation of the sacrificial anode.

\section{Discussion}

The methodology proposed in section 2.2.1 together with other relevant archaeological evidences, allowed the Underwater Archaeology Centre of Andalusia, to name each wreck (García-Rivera and AlzagaGarcía, 2012).

Both ships of the line, the eighty cannons S.M.I. Bucentaure and the seventy-four cannons S.M.I. Fougueux, belonged to the Franco-Spanish fleet in the Battle of Trafalgar (1805) and were sunken during the violent storm that struck the coast of Cadiz during the following days after the battle.

The concretions formed around these cannons and anchors acted as a semi-permeable membrane and appears to physically separate the anodic and cathodic sites (North, 1976). After several years the inner regions of the concretion have become acidic, presumably due to the hydrolysis of the ferrous and ferric ions and the slow exchange of the solution through the concretion with the surrounding alkaline sea water, and under this concretion the chloride concentration is high too, propitiating pitting and uniform or general corrosion of iron. Oxygen reduction, presumably on the seaward surface of the concretion, appears to be the major cathodic reaction for corrosion of exposed artefacts on the sea bed. For buried iron objects the major cathodic reaction may be the reduction of sulphate ions by bacteria.

The presence of graphite flakes in the metallographic analysis made on the cannon extracted from the Bucentaure shipwreck is the result of the addition of a substantial amount of silicon (around $0.3 \%$ ) to a relatively low carbon cast iron (just over $2 \%$ ), which induces also the cementite to ferrite transformation (Radzikowska, 2004; Ruxanda and Stefanescu, 2004). This influence in the properties of the resultant metal, making it easier to machine and improving wear resistance. In Samuels (1992) Samuels examined a small grey cast iron cannon from the Endeavour (1770), showing that cannon was corroded in a characteristic manner, termed graphitization by corrosion technologists, and found areas of ferrite in the microstructure corrode first, then cementite, but graphite phase was not affected. Samuels indicates that graphite is anodic with respect to ferrite and cementite, and so its presence accelerates the corrosion of the two matrix phases, particularly at a graphite-ferrite interface. The end result is that the matrix of the alloy corrodes completely but is held together by the graphite flakes interconnected in a three dimensional network, similar to those observed by Samuels, which holds the corrosion products together and so retains the original shape and surface details.

The presence of the mineral phases of the corroded surface shown in Table 1 is not due to the same process of formation: akaganeite, $\mathrm{Fe}^{3+}$ $\mathrm{O}(\mathrm{OH})\left(\mathrm{Cl}_{0.19}\right)$ is the oxyhydroxide of the $\beta$-phase of the iron containing maximum $7 \mathrm{wt} \%$ of $\mathrm{Cl}^{-}$ions in its structure, and is a corrosion product of iron in environments that contain chloride, normally observed in archaeological iron objects from marine sites, and can also be present in meteorites and its structure is thoroughly studied in these different contexts (Réguer et al., 2009; Réguer et al., 2015). It has a crystalline structure of the hollandite type, one of the most frequent types of morphology in which this mineral is found (Cornell and Giovanoli, 1990), and contains cavities of tubular appearance where the chloride ions reside (Mackay, 1962).

In marine corrosion, specifically for very long periods, it is generally admitted that corrosion products of iron artefacts immersed in seawater are mainly composed of magnetite $\left(\mathrm{Fe}_{3} \mathrm{O}_{4}\right)$, goethite $(\alpha-\mathrm{FeOOH})$ or an iron oxyhydroxide containing chlorine, akaganeite $\left(\beta-\mathrm{FeOOHCl}_{\mathrm{x}}\right)$ (Selwyn, 2004), formed in the inner part of the corrosion layer, near the metal-oxide interface of corroded artefacts. Following the classic model of general corrosion layout in archaeological ferrous artefacts proposed by Neff et al. (2005) and Neff et al. (2006), Fig. 14 shows the schematic diagram of the corrosion layout characterized in this paper. This layout observed on a cross section of the sample is made of successive layers. The metal core of archaeological iron objects is normally covered by dense products layers (DPL), which are constituted by iron oxides and oxyhydroxides and appears relatively dense, compared to the more external layers. DPL's are constituted by more or less numerous magnetite or maghemite strips entrapped in matrix. A more external layer is named by these authors transformed medium (TM). This contains simultaneously corrosion products and exogenous compounds from the environment such as quartz grains.

But the presence of $\beta-\mathrm{FeOOH}$ in the corrosion layer is still open to discussion. Refait et al. (Refait and Génin, 1997; Refait et al., 1998) observed the formation of $\beta-\mathrm{FeOOH}$ as a result from the oxidation of a
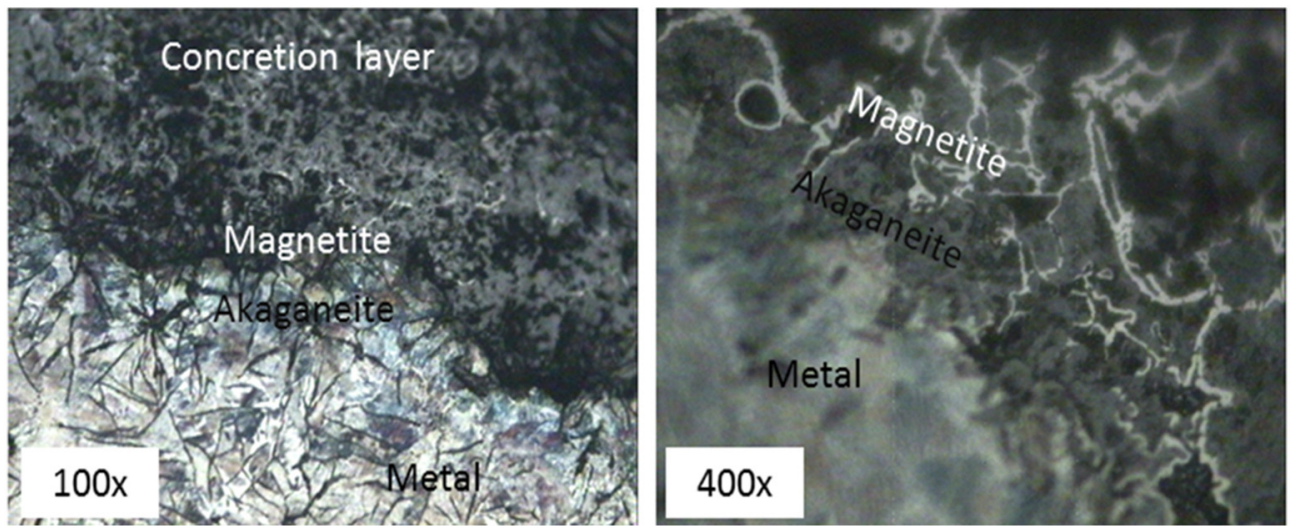

Fig. 11. Micrographs of the outer part of the corrosion layer. Sample etched with $5 \%$ Nital, $100 \times$ and $400 \times$ respectively. 

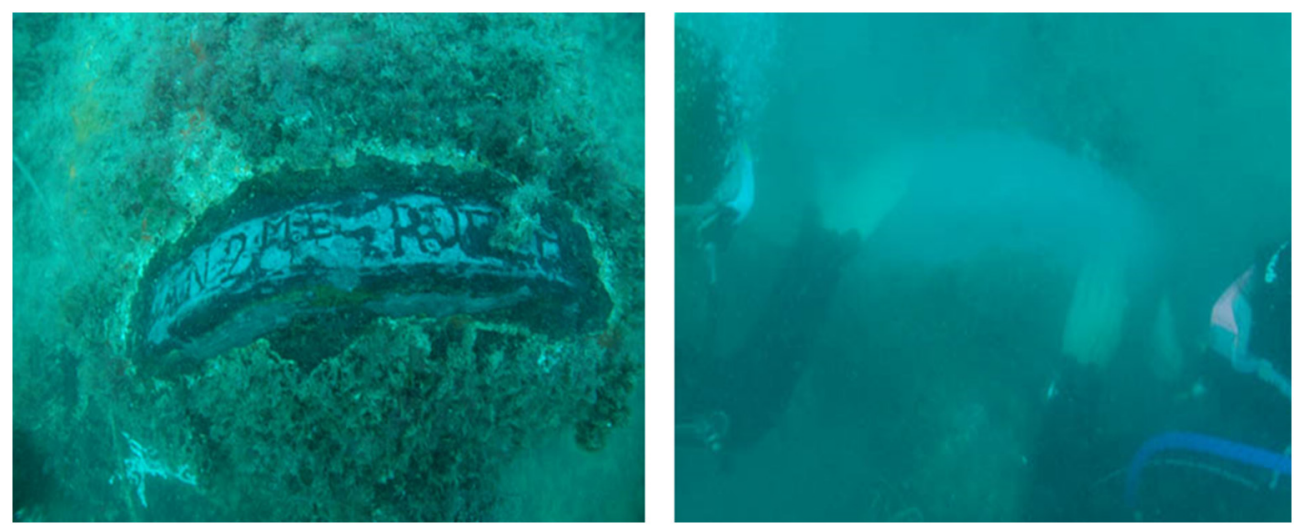

Fig. 12. Stamps on a Fougueux cannon breech (left). Recovering the stability with two components epoxy coating (right). From: Underwater Archaeology Centre of Andalusia.

specific compound, the $\mathrm{Fe}(\mathrm{II})$ hydroxychloride $\beta-\mathrm{Fe}_{2}(\mathrm{OH})_{3} \mathrm{Cl}$, and authors as Turgoose (1982) and Selwyn et al. (1999) hypotheses that akaganeite is formed only after excavation, but it was never demonstrated by archaeological artefact precise studies. Finally, Reguer et al. (2015) shows the presence of $\beta-\mathrm{Fe}_{2}(\mathrm{OH})_{3} \mathrm{Cl}$ in corrosion products extracted from a corroded wrought iron bar found in a gallo-roman shipwreck (50 AD), but not in cast iron objects.

Réguer et al. (2007) showed the presence of two chlorides containing phases with different crystallographic structures and different Fe oxidation states in the corrosion products formed on ferrous archaeological artefacts buried in soil. The common oxyhydroxide akaganeite $\beta$-FeOOH was identified in the zones containing 5-8\% mass of chloride, while in the zones with a more higher chloride content, which is about $15-20 \%$ mass, the ferrous hydroxychloride $\beta-\mathrm{Fe}_{2}(\mathrm{OH})_{3} \mathrm{Cl}$ was found. However, our analysis does not show the presence of this phase. Reguer indicates that it is possible to classify the iron archaeological samples in different types of layouts depending on the phase presence and distributions. In some cases, only one phase, akaganeite (type 1) or ferrous

Table 2

Parameters of in situ corrosion in Bucentaure and the Fougueux. In Fougueux site, cannons in shaded rows are located near the edges of the reef.

\begin{tabular}{|c|c|c|c|c|}
\hline Object & $\begin{array}{l}\text { Corrosion layer } \\
\text { thickness }(\mathrm{mm})\end{array}$ & $\begin{array}{l}\text { Average corrosion rate } \\
\text { (mm/year) }\end{array}$ & $\mathrm{E}_{\text {corr }} \mathrm{VsAg} / \mathrm{AgCl}(\mathrm{mV})$ & $\mathrm{pH}$ \\
\hline \multicolumn{5}{|c|}{ Bucentaure site } \\
\hline Cannon 1 & 19 & 0.093 & -0.567 & 5.92 \\
\hline Cannon 2 & 21 & 0.103 & -0.541 & 5.71 \\
\hline Cannon 3 & 23 & 0.113 & -0.539 & 5.65 \\
\hline Cannon 4 & 21 & 0.103 & -0.543 & 5.70 \\
\hline Cannon 5 & 22 & 0.108 & -0.541 & 5.65 \\
\hline Cannon 6 & 21 & 0.103 & -0.533 & 5.50 \\
\hline Cannon 7 & 23 & 0.113 & -0.497 & 5.60 \\
\hline Cannon 8 & 17 & 0.083 & -0.568 & 5.94 \\
\hline Cannon 9 & 20 & 0.098 & -0.551 & 5.87 \\
\hline Cannon 10 & 19 & 0.093 & -0.563 & 5.92 \\
\hline Cannon 11 & 21 & 0.103 & -0.549 & 5.69 \\
\hline Cannon 14 & 20 & 0.098 & -0.555 & 5.86 \\
\hline Cannon 15 & 24 & 0.118 & -0.537 & 5.59 \\
\hline Cannon 16 & 25 & 0.123 & -0.534 & 5.56 \\
\hline Cannon 17 & 23 & 0.113 & -0.540 & 5.59 \\
\hline Cannon 21 & 20 & 0.098 & -0.552 & 5.86 \\
\hline Cannon 22 & 15 & 0.073 & -0.580 & 6.01 \\
\hline Cannon 23 & 26 & 0.128 & -0.542 & 5.45 \\
\hline Anchor & 58 & 0.285 & -0.484 & 4.58 \\
\hline \multicolumn{5}{|c|}{ Fougueux site } \\
\hline Cannon 4 & 50 & 0.246 & -0.460 & 5.21 \\
\hline Cannon 5 & 48 & 0.236 & -0.475 & 5.29 \\
\hline Cannon 6 & 41 & 0.201 & -0.496 & 5.50 \\
\hline Cannon 9 & 47 & 0.231 & -0.488 & 5.33 \\
\hline Cannon 10 & 48 & 0.236 & -0.473 & 5.26 \\
\hline Cannon 11 & 39 & 0.192 & -0.503 & 5.75 \\
\hline Cannon 12 & 46 & 0.226 & -0.492 & 5.41 \\
\hline Cannon 13 & 40 & 0.197 & -0.497 & 5.55 \\
\hline Cannon 14 & 39 & 0.192 & -0.502 & 5.69 \\
\hline Cannon 15 & 36 & 0.176 & -0.496 & 6.00 \\
\hline Cannon 16 & 38 & 0.187 & -0.525 & 5.91 \\
\hline Cannon 17 & 37 & 0.182 & -0.541 & 5.95 \\
\hline Cannon 18 & 38 & 0.187 & -0.524 & 5.80 \\
\hline Cannon 19 & 38 & 0.187 & -0.513 & 5.76 \\
\hline Cannon 20 & 39 & 0.192 & -0.501 & 5.66 \\
\hline Cannon 21 & 49 & 0.241 & -0.468 & 5.25 \\
\hline Cannon 22 & 50 & 0.246 & -0.455 & 4.58 \\
\hline Cannon 24 & 41 & 0.201 & -0.495 & 5.48 \\
\hline Cannon 25 & 43 & 0.212 & -0.495 & 5.43 \\
\hline Anchor & 64 & 0.315 & -0.430 & 4.43 \\
\hline
\end{tabular}




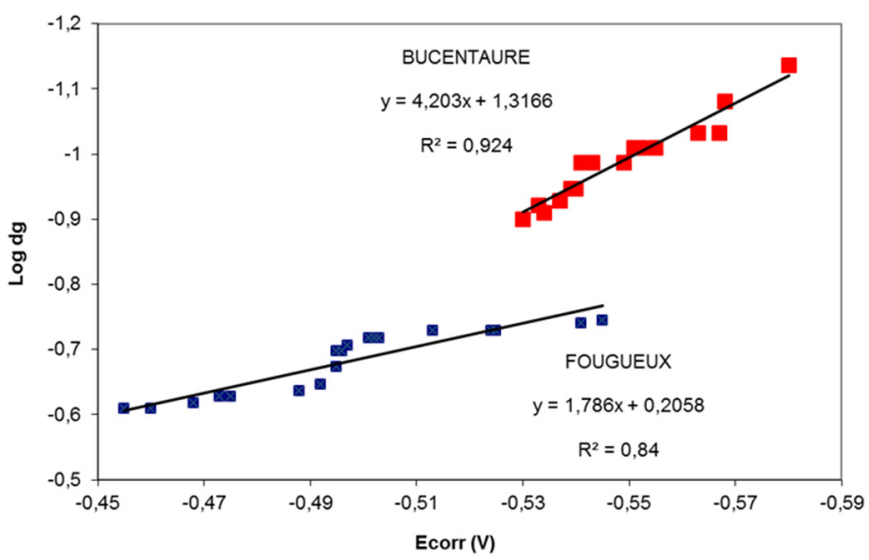

Fig. 13. Plot of the logarithm of annual corrosion rate in the cannons versus $\mathrm{E}_{\mathrm{corr}}$ in situ (Ag/ $\mathrm{AgCl}$. a) The Bucentaure site, b) The Fougueux site.

hydroxychloride (type 2 ) is identified at the metal/oxide interface. In other cases (types 3a, 3b, 3c), the two phases are present as alternate layers or spots of one phase in the other one. Reguer noted that the more ancient excavated artefacts show only type 1 layouts, but no ferrous hydroxychloride, because too long exposure to the atmosphere with continuous oxygen supply implies the oxidation of $\beta-\mathrm{Fe}_{2}(\mathrm{OH})_{3} \mathrm{Cl}$ into $\beta-\mathrm{FeOOH}$.

Other compounds found in our analysis were magnetite $\left(\mathrm{Fe}_{3} \mathrm{O}_{4}\right.$ or $\mathrm{FeO} \cdot \mathrm{Fe}_{2} \mathrm{O}_{3}$ ), an oxide where the iron has two states of oxidation, $\mathrm{Fe}^{3+}$ and $\mathrm{Fe}^{2+}$, and siderite $\left(\mathrm{FeCO}_{3}\right)$, iron(II) carbonate produced by anaerobic corrosion, by direct precipitation or involving sulphate reduction to $\mathrm{Fe}^{2+}$. In this last case, the excess of $\mathrm{Fe}^{2+}$ with respect to $\mathrm{SH}^{-}$in the presence of $\mathrm{HCO}_{3}^{-}$causes the precipitation of siderite. Both magnetite and siderite are typical products of the corrosion processes during the formation of the concretions (Al Agha et al., 1995). Quartz and plagioclase albite, $\mathrm{NaAlSi}_{3} \mathrm{O}_{8}$, are compounds present in marine sediments, the environment in which the object has undergone the corrosionconcretion process. In Cvikel et al. (2013) Cvikel et al. found quartz, but in this case in internal cavities inside a 9-pdr and a 24-pdr cannonballs from the Akko 1 shipwreck (beginning of the 19th century, Akko harbor, Israel), probably originated in the sandcasting. Quartz is common in the eastern Mediterranean.

Reguer proposed a mechanism to explain the different corrosion layouts and the appearance of akaganeite and/or $\beta-\mathrm{Fe}_{2}(\mathrm{OH})_{3} \mathrm{Cl}$. The mechanisms induced in the thick layers can generate the oxygen deficit at the $\mathrm{M} / \mathrm{DPL}$ interface, implying the potential decrease and a reductive environment at same place. Depending on the $\mathrm{O}_{2}$ content at the M/DPL interface akaganeite or $\beta-\mathrm{Fe}_{2}(\mathrm{OH})_{3} \mathrm{Cl}$ will precipitate. If cracks appear, causing $\mathrm{O}_{2}$ supply, $\beta-\mathrm{Fe}_{2}(\mathrm{OH})_{3} \mathrm{Cl}$ can locally oxidize and lead to the formation of the alternate layout of type 1 and type 2 zones. The presence of these cracks in ancient corrosion layer was widely mentioned in literature. Two possibilities have to be distinguished. The first assumption implies the presence of a crack oriented perpendicular to the M/DPL interface and which crosses the two $\mathrm{Cl}$-containing phases. This situation leads to the oxidation of $\beta-\mathrm{Fe}_{2}(\mathrm{OH})_{3} \mathrm{Cl}$, which would remain only in the form of small spots in favour of the expansion of the akaganeite layer. This would be our case. The second hypothesis suggests the

Table 3

Corrosion parameters measured in situ on cannon no. 6 (Bucentaure site), before and after connection to the anode.

\begin{tabular}{lllll}
\hline Cannon no. 6 & $\begin{array}{l}\text { Before } \\
\text { protection }\end{array}$ & $\begin{array}{l}30 \mathrm{~min} \\
\text { later }\end{array}$ & $\begin{array}{l}9 \text { months } \\
\text { later }\end{array}$ & $\Delta \mathrm{E}_{\text {corr }} / / \Delta \mathrm{pH}$ \\
\hline $\begin{array}{l}\mathrm{E}_{\text {corr }} \text { vs } \mathrm{Ag} / \mathrm{AgCl}(\mathrm{mV}) \\
\mathrm{pH}\end{array}$ & $-533 \mathrm{mV}$ & $-540 \mathrm{mV}$ & $-628 \mathrm{mV}$ & $95 \mathrm{mV}$ \\
& 5.50 & - & 7.2 & 1.7 \\
\hline
\end{tabular}

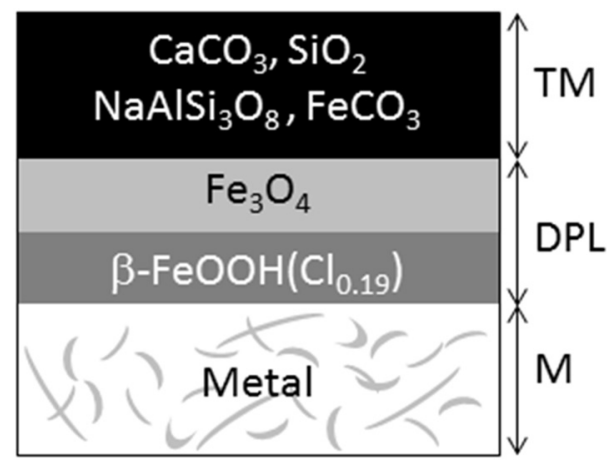

Fig. 14. Scheme of the characterized corrosion layer, based in the classic model proposed by Neff et al. (2005) and Neff et al. (2006). See text for an explanation of the symbols.

presence of cracks through the DPL but which does not cross the two $\mathrm{Cl}$-containing phases. Then, $\beta-\mathrm{Fe}_{2}(\mathrm{OH})_{3} \mathrm{Cl}$ oxidizes into $\beta$-FeOOH. The resulting layout contains the two phases with alternate distribution.

Well-preserved archaeological iron artefacts in marine sites are exceptional and may only have survived because some layers of corrosion products on their surfaces protected them or the soil in which they have been buried has been non-aggressive.

The presence of these layers of corrosion products on the surface of iron artefacts plays an important role in the corrosion mechanisms, and may become more or less protective depending on $\mathrm{pH}$, the time elapsed or the phases that constitute them, being able to slow down the corrosion process (Wranglén, 1985; Cronyn, 1990). For instance, it seems that the cathodic reaction location can move in the corrosion scale during the corrosion process (Neff et al., 2005). Objects with phosphates and specially carbonates layers around the metal core are especially well-preserved (Wranglén, 1985; Booth et al., 1962). But such protective layers on the surface of archaeological objects may also save and hide important scientific information about the object itself (decoration, stamps, etc.). Often, the former surface of an archaeological object ('original surface') has been preserved under a sequence of corrosion layers. This original surface is critical for archaeologists trying to reconstruct the former function of an object.

MacLeod (1981) proposed that once the acidic environment was established inside the concretions of a cannon and an anchor at Ningaloo site, hydrogen discharge might make a significant contribution to the net cathodic reaction. An estimation of the corrosion rates of these iron artefacts could be made assuming zero ohmic drop $\left(i_{R}\right)$ and that the rate was determined by the hydrogen discharge on iron. For cannon (cast iron) corrosion rates vary from 10 to $30 \mu \mathrm{A} \mathrm{cm}^{2}$ depending on the hydrogen partial pressure ( 0.01 to $1 \mathrm{~atm}$ respectively). Macleod estimated in this site that after 170 years this would amount to a corrosion depth of between 6 and $2 \mathrm{~cm}$; later experimental drilling showed that solid metal was reached at a depth of $2.5 \mathrm{~cm}$ from the original surface. In the case of the wrought iron anchor the corrosion rate was calculated at between 2 and $6 \mu \mathrm{A} \mathrm{cm} \mathrm{cm}^{-2}$ for hydrogen pressures of between 0.01 and $1 \mathrm{~atm}$ giving a corrosion depth of between 0.4 and $1.2 \mathrm{~cm}$ since the shipwreck. The extent of corrosion of the anchor varied considerably but was within the calculated range.

In Bucentaure cannons, numbers 1, 3 and 22 (Fig. 3) showed concretion layers in bands, with alternating black corrosion products, symptomatic of the fluctuations that may have suffered during periods of burial and exhumation in the sediment. The location of these guns coincides with the areas in which the erosion-accretion model shows greater variations (Fig. 5a), i.e. areas where erosion and deposition rates are higher. Because of the partial protection in periods of burial, these cannons are less corroded than the rest in the same site.

Particularizing, this difference in microenvironments is much more pronounced in the case of the cannon no. 22 which has undergone a low degree of corrosion in these two centuries, with a depth of 
graphitization of only $0.073 \mathrm{~mm}$ (a factor of 3 times smaller than in the case of some cannons of Fougueux).

There are environmental variables in the water column that show small differences between the two sites and may promote a higher corrosion rate in the Fougueux (case of dissolved oxygen and temperature slightly higher in the Fougueux). Other variables as salinity or $\mathrm{pH}$ do not differ between the two sites. However, as shown in the results section, the greatest differences in the environmental conditions observed of both sites are related to the physical factors, especially the wind waves and the processes of resuspension and sediment transport. These processes are more important at Fougueux, which is exposed to a more energetic wave regime and has a smaller sediment grain size, facilitating resuspension and transport.

In the case of Fougueux the relevance of these physical factors is evident if we consider that its cannons present clearly different corrosion rates according with their positions and exposure to the waves and sediment resuspension, while at Bucentaure all cannons have nearly identical rates.

Other differentiating factors between one and another site are the biological communities. The Fougueux is exposed to an amount of unstable or more changing environmental conditions related to waves (Fernández-Montblanc et al., in press) and seasonal changes in the biological community have been observed, which is not the case at Bucentaure site. In addition it should be noted that algae characterize the sessile community at Fougueux site in both natural substrate and artificial substrate, whereas at Bucentaure site the biological communities at natural substrate and artificial substrate are characterized by species that produce $\mathrm{CaCO}_{3}$ concretions such as serpulid polychaetes and barnacles. It can be related with the result of biological concretion measurement achieved in metallic artefacts at both shipwreck sites, a thin layer on the objects of the Fougueux, and a thick layer on those of the Bucentaure. In subtropical waters, organisms with exoskeleton of $\mathrm{CaCO}_{3}$ can growth on iron archaeological objects forming a thin layer across the surface of these materials (North, 1976). This exoskeleton remains after the death of the organisms and the thick layers of $\mathrm{CaCO}_{3}$ formed over the surfaces of cannons and anchors seems to provide a suitable substrate for secondary growth of seaweed, soft corals, molluscs, etc. (Casoli et al., 2015; Railkin, 2004).

Concretion forms a semipermeable barrier between the iron and the seawater and tends to modify the corrosion behavior of the iron. Where the concretion is thin, the diffusion processes through it are greater, allowing corrosion during the life of the object. When cannons and anchors are colonized by organisms, and thus encapsulated, the separation of the metallic elements from the direct impact of the dissolved oxygen leads to the development of a corrosion microenvironment that is essentially free of oxygen at the metal concretion interface. In this environment, the $\mathrm{pH}$ is controlled by the hydrolysis of the primary corrosion products and the interaction of this acidic solution with the calcareous encapsulating organisms. The details of this interaction for ferrous materials are provided in North (1976). Fig. 15 summarized the influence of these factors on the conservation state in each site.

Through sequential measurements on the $\mathrm{pH}$ and the voltage of the calcareous concretion surrounding cannons and anchors, it is possible to obtain a profile that correlates well with the oxidation states found in a standard Pourbaix diagram for iron in the marine environment with a chloride level of $1.5 \mathrm{M}$. The voltages in the outer zone of the concretion reflect the redox potential of $\mathrm{Fe}^{3+} / \mathrm{Fe}^{2+}$ which progressively fall until the true corrosion potential of the iron alloy is obtained. The values of $\mathrm{pH}$ and corrosion potentials presented in the above tables have been located on a Pourbaix diagram similar to Fig. 16 (Pourbaix, 1963). The choice of the temperature for the diagram is determined by the average temperature of both sites. In the diagram, in yellow is the region where the ferrous ion, $\mathrm{Fe}^{2+}$, is the thermodynamically favored state of iron. All studied objects, including the anchors, are located in this region of stability, in which metal is freely corroding in the absence of any protective oxide layer like $\mathrm{Fe}_{2} \mathrm{O}_{3} \cdot \mathrm{XH}_{2} \mathrm{O}$. The domain of ferrous ion is also indicative that the environment under the concretion layer is low in oxygen (reducing), while the face in contact with the ocean is associated with a highly oxygenated environment.

There is a good correlation between the corrosion potential $\mathrm{E}_{\mathrm{corr}}$ and $\mathrm{pH}$. Oxidation of the metal matrix to produce ferrous ions partially hydrolyzed gives the same dependence, as empirically observed; therefore, the equation:

$\mathrm{Fe}+\mathrm{H}_{2} \mathrm{O} \rightarrow \mathrm{Fe}(\mathrm{OH})^{+}+\mathrm{H}^{+}+2 \mathrm{e}^{-}$

should give the same dependence of corrosion potentials on $\mathrm{pH}$, as observed experimentally. A close inspection of the Pourbaix diagram of Fig. 16 shows that the data are not in the area of stability $\mathrm{FeOH}^{+}$ions and hence the Eq. (4) is not accurately describing the process. Since corrosion is occurring in seawater, a reaction scheme should incorporate chloride ions in the corrosion products:

$2 \mathrm{Fe}+2 \mathrm{H}_{2} \mathrm{O}+2 \mathrm{Cl}^{-} \rightarrow \mathrm{FeCl}_{2} \mathrm{Fe}(\mathrm{OH})_{2}+2 \mathrm{H}^{+}+4 \mathrm{e}^{-}$

The partially hydrolyzed iron chloride similar to the hypothesis by Eq. (4) $\left(\mathrm{FeCl}_{2} \cdot \mathrm{Fe}(\mathrm{OH})_{2}\right)$ has been identified as an important intermediate reaction in the corrosion of iron marine ecosystems. The above equation gives the same dependence of the corrosion potential with the $\mathrm{pH}$ of the microenvironment as observed experimentally. Thus, a faster corrosion rate will produce a greater acidification on the surface of the corrosion of metals that are below the marine concretion.

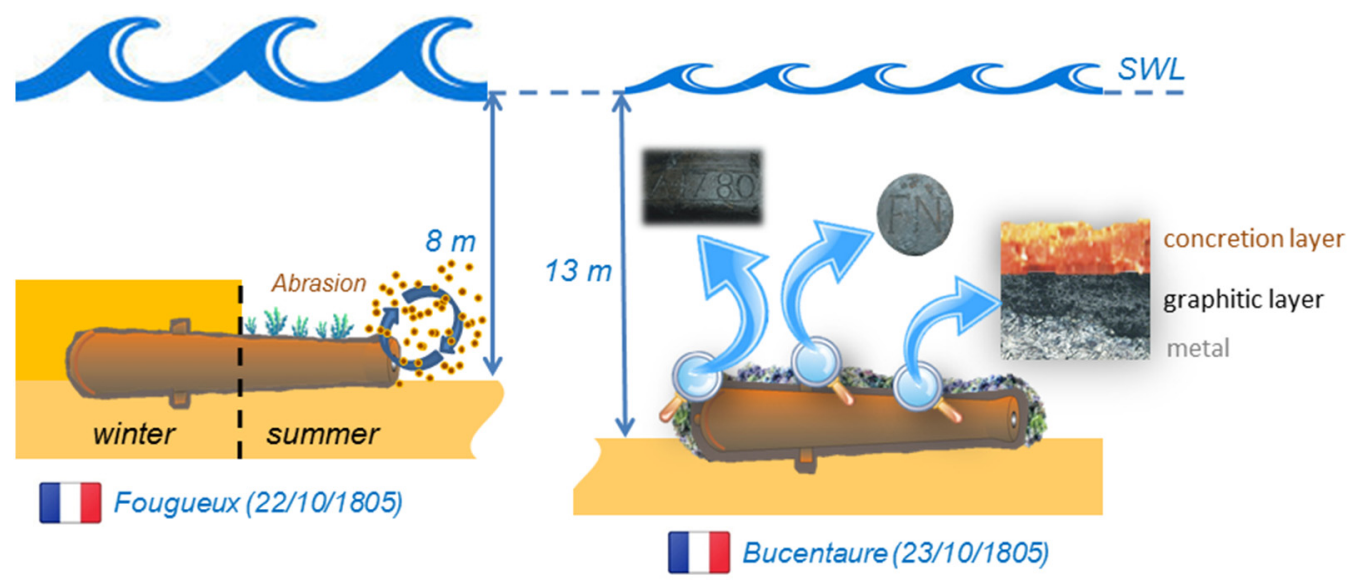

Fig. 15. Conceptual model summarized the processes and patterns together. 


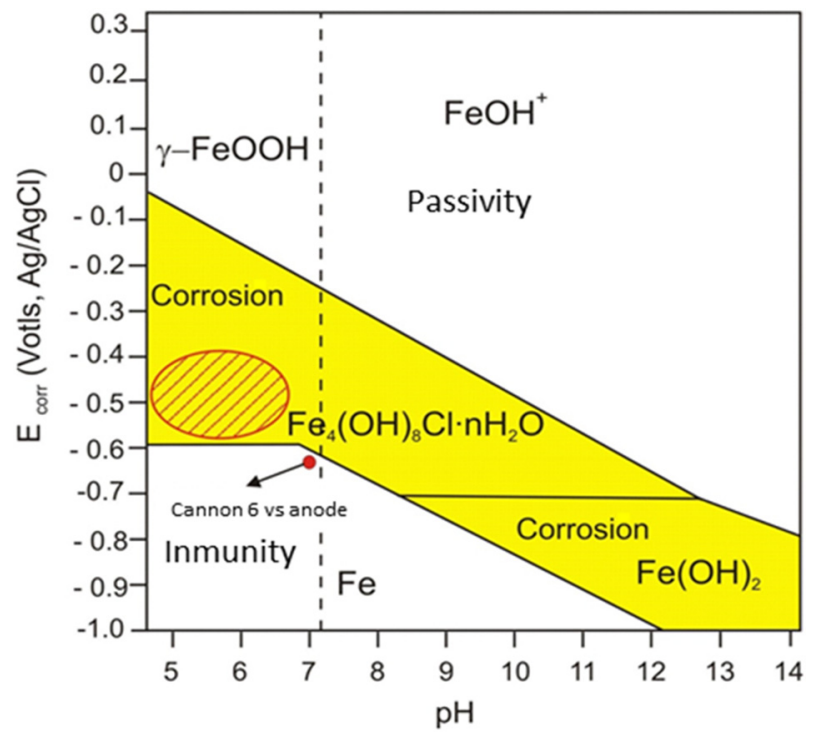

Fig. 16. Simplified Pourbaix diagram for iron (adapted from Pourbaix, 1963).

As for the concretions layers associated with the anchors of both sites it was visually observed that these were denser than the cannons in the same environment. The corrosion potential and $\mathrm{pH}$ of the anchors placed them on the edge of the area of stability of water, with respect to reduction of hydrogen. The state of both anchors can be described as high corrosion. Since anchors are made of iron forging (very different from the casting of a cannon), they must have a low carbon and iron will be in a more active form. The only justifiable cause of the misbehavior against corrosion is the compositional difference.

From the analysis of these data a shift in corrosion potential toward the zone of immunity of iron in seawater (Fig. 16) is observed. Furthermore, an increase in $\mathrm{pH}$ is observed, which shows that the electron flow in the cannon causes a decrease in acidity levels in the solution trapped in the interface metal-concretion due to the processes of hydrogen evolution. Some authors argue that the change of Molarity in the object can lead to the beginning of chloride remobilization processes, hypothesis that has not been certified.

The effect of the anode on the cannon no. 6 (Bucentaure site) can be estimated, considering the Eq. (2a) with the experimental results shown in the above table as a basis for comparison before and after introduction of the anode. By replacing the corrosion potential value from Table 2 in Eqs. (2a), the value of the corrosion rate of cannon no. 6 at the time which it was connected to the sacrificial anode is obtained. By comparing the corrosion rate presented in Table 2 and the average corrosion rate obtained by connecting the anode, the percentage value of corrosion rate, negative if successful, positive if the system used is detrimental for the cannon (i.e. cathodic overprotection) is obtained. These data are showed in Table 4.

The end result is the decrease in corrosion potential and corrosion rate of the cannon no. 6 , while the anode is consumed and must be finally replaced. The results obtained for cannon no. 6 indicate that the use of the anode was effective, reducing the average corrosion rate and the percent of corrosion rate.

Table 4

Corrosion rates at cannon no. 6 before and after the connection to the anode.

\begin{tabular}{llll}
\hline Cannon no. 6 & Before protection & 30 min later & 9 months later \\
\hline Corrosion rate (mm/year) & 0.103 & 0.094 & 0.064 \\
Corrosion rate percent & - & -8.74 & -37.86
\end{tabular}

\section{Conclusions}

This work brings a new useful element in conservation techniques and archaeological documentation applied to both management and the scientific knowledge of UCH. With its launch, it has been developed a monitoring protocol for in situ conservation studies and documentation, as well as new research tools on the resources of the UCH.

Thus, in situ measurements made on the cannons and anchor in Fougueux shipwreck indicate that some of the pieces are corroding at a higher rate, probably due to high levels of water movement in the edges of the reef in this site. While the cannons of Bucentaure are well preserved and archaeological information in the graphitic zone is guaranteed, the anchor details on the original surface, if any, are in danger due to the misbehavior of its remaining metal, based in wrought iron with low carbon content.

The Bucentaure cannons do not present an imminent danger of collapse. Thus, the efforts for in situ maintenance should be focused on artillery pieces from the Fougueux.

Physical conditions have a crucial role in the degradation of the shipwrecks. The highest rates of corrosion were measured on cannons placed in Fougueux site, which is subjected to higher energetic conditions due to wave action. Sediment remobilization and transport induced by waves in Fougueux site could cause the damage by direct mechanical effect on metallic material as well as removing the layer of corrosion products developed on these along with the decrease of calcareous concretion thickness, having a direct negative impact on their conservation status.

Knowledge of the physical and hydro-chemical conditions is necessary, because they can contribute to the development of different types of sessile community: dominated by algae or with a greater presence of barnacles and polychaetes, whose calcareous depositions seem to contribute positively to the UCH conservation.

If the management of these objects finally goes through in situ conservation following the principles of the UNESCO Convention, the use of sacrificial anodes has proved an effective tool for maintaining the stability conditions.

These results could be used to develop a decision making system, based on predictive models of permanence through the knowledge of materials and analysis of risk factors imposed by the marine environment.

\section{Acknowledgments}

This work was supported by the Spanish Ministry of Economy and Competitiveness and FEDER, Project CTM2010-16363 (ARQUEOMONITOR). The coordinates of the Fougueux and Bucentaure sites and Fig. 12 were supplied by The Underwater Archaeology Centre of Andalusia. Their studies are needed to understand the history of these ships.

\section{References}

Al Agha, M.R., Burley, S.D., Curtis, C.D., Esson, J., 1995. Complex cementation textures and authigenic mineral assemblages in recent concretions from the Lincolnshire Wash (east coast, UK) driven by Fe(0) to Fe(II) oxidation. J. Geol. Soc. 152, 157-171.

Bartuli, C., Petriaggi, R., Davidde, B., Palmisano, E., Lino, G., 2008. In situ conservation by cathodic protection of cast iron findings in marine environment. 9th International Conference on NDT of Art, Jerusalem, pp. 1-7.

Bergstrand, T., Godfrey, I.N., 2007. Reburial and Analyses of Archaeological Remains Studies on the Effect of Reburial on Archaeological Materials Performed in Marstrand, Sweden 2002-2005, the RAAR Project, Bohusläns Museum och Studio Västsvensk Konservering.

Bethencourt, M., Zambrano, L.C., 2002. In: Roldán, Clodoaldo (Ed.), Desarrollo y aplicación de una técnica combinada para la conservación y registro arqueológico en yacimientos submarinos Ponencias del IV Congreso Nacional de Arqueometría. Unidad de Arqueometría. ICMU, pp. 1-6.

Bethencourt, M., Gil, M.L.A.,Fernández-Lorenzo, C Santos, A. 2004. Aplicación de tratamiento electroquímico a baja intensidad de corriente para la extracción de cloruros en objetos arqueológicos de hierro de procedencia subacuática. Observación 
de la evolución de fases mineralógicas mediante XRD-Rietveld. Revista de Metalurgia Madrid 40, 420-425.

M. Bethencourt, F.J. Botana, M. Marcos, Sistema combinado para el registro y la conservación arqueológica subacuática in situ. Patent: 2221 525, Spain. Registred in: 24/05/2002. Granted in: 08/09/2005.

Björdal, C.G., Nilsson, T., 1998. Laboratory reburial experiments. In: Hoffmann, P., BonnotDiconne, C., Hiron, X., Tran, Q.K. (Eds.), The 7th ICOM-CC Working Group on Wet Organic Archaeological Materials Conference. ICOM, Grenoble, pp. 71-77.

Björdal, C.G., Nilsson, T., 2008. Reburial of shipwrecks in marine sediments: a long-term study on wood degradation. J. Archaeol. Sci. 35, 862-872.

Björdal, C.G., Daniel, G., Nilsson, T., 2000. Depth of burial, an important factor in controlling bacterial decay of waterlogged archaeological poles. Int. Biodeterior. Biodegrad. $45,15-26$.

Blott, S.J., Pye, K., 2001. Gradistat: a grain size distribution and statistics package for the analysis of unconsolidated sediments. Earth Surf. Process. Landf. 26, 1237-1248.

Booth, G.H., Tiller, A.K., Wormwell, F., 1962. Ancient iron nails well preserved from apparently corrosive soils. Nature 195, 376-377.

Bray, J.R., Curtis, J.T., 1957. An ordination of the upland forest communities of Southern Wisconsin. Ecol. Monogr. 27, 325-349.

Casoli, E., Ricci, S., Belluscio, A., Gravina, M.F., Ardizzone, G., 2015. Settlement and colonization of epi-endobenthic communities on calcareous substrata in an underwater archaeological site. Mar. Ecol. 36, 1060-1074.

Clarke, K.R., 1993. Non-parametric multivariate analyses of changes in community structure. Aust. J. Ecol. 18, 117-143.

Clarke, K.R., Gorley, R.N., 2006. PRIMER-E v6: user manual/tutorial. Plymouth: PRIMER-E. Available from:. http://www.primer-e.com/Primary_papers.htm.

Cornell, R.M., Giovanoli, R., 1990. Transformation of akaganéite into goethite and hematite in alkaline media. Clay Clay Miner. 38 (5), 469-476.

Cronyn, J.M., 1990. The Elements of Archaeological Conservation. Routledge, London.

Curci, J., 2006. The reburial of waterlogged archaeological wood in wet environments. Tech. Briefs Hist. Archaeol. 1, 21-25.

Cvikel, D., Ashkenazi, D., Stern, A., Kahanov, Y., 2013. Characterization of a 12-pdr wrought-iron cannonball from the Akko 1 shipwreck. Mater. Charact. 83, 198-211.

El-Rayis, O.A., 1985. Re-assessment of the tritration method for determination of organic carbon in recent sediments. Rapp. Comm. Int. Mer Méditer. 29 (7), 45-47.

European Convention on the Protection of the Archaeological Heritage (Revised), 19921. Valletta, 16-1-1992, European Treaty Series No. 143, Council of Europa.

Fernández-Montblanc, T., Quinn, R., Izquierdo, A., Bethencourt, M., 2016. Evolution of a shallow water wave-dominated shipwreck site: Fougueux (1805). Gulf of Cadiz, Geoarchaeology 31:487-505. http://dx.doi.org/10.1002/gea.21565.

García-Rivera, C., Alzaga-García, M., 2012. The underwater archaeological heritage of Andalusia: actions for the protection of an emerging heritage. Eur. J. Archaeol. 15 (2), $257-274$.

Green, J., 2004. Maritime Archaeology. A Technical Handbook. Elsevier Academic Press, California (470 pp.).

Gregory, D., 1995. Experiments into the deterioration characteristics of materials on the Duart Point wreck site: an interim report. Int. J. Naut. Archaeol. 24 (1), 61-65.

Gregory, D., 1998. Re-burial of timbers in the marine environments as a means of their long-term storage: experimental studies in Lynas Sands, Denmark. Int. J. Naut. Archaeol. 27, 343-358.

Gregory, D., 1999. Monitoring the effect of sacrificial anodes on the large iron artefacts on Duart Point wreck, 1997. Int. J. Naut. Archaeol. 28 (1), 164-173.

Gregory, D., 2009. In situ preservation of marine archaeological sites: out of sight but not out of mind. In: Richards, V., McKinnon, J. (Eds.), In Situ Conservation of Cultural Heritage: Public, Professionals and Preservation. Flinders University, Adelaide, pp. 1-16.

Grupo de Ingeniería Oceanográfica y de Costas (GIOC), 2001. Propagation Model of Spectral Wave (OlucaSP 2.0). Reference Manual. Modelo de Ayuda a la Gestión del Litoral Español, Edición Univ. de Cantabria-Ministerio de Medio Ambiente (170pp.).

Kim, Y.S., Singh, A.P., Nilsson, T., 1996. Bacteria as important degraders in waterlogged archaeological woods. Holzforschung 50, 389-392.

MACHU Project, 2009. http://www.machuproject.eu/.

Mackay, A.L., 1962. Beta-ferric oxyhydroxide, akaganeite. Mineral. Mag. 33, 270-280.

MacLeod, I.D., 1981. Shipwrecks and applied electrochemistry. J. Electroanal. Chem. 118, 291-304.

MacLeod, I.D., 1995. In situ corrosion studies on the Duart Point wreck. Int. J. Naut. Archaeol. 24, 53-59.

MacLeod, I.D., 2002. In situ corrosion measurements and management of shipwreck sites. In: Ruppé, C.V., Barstad, J.F. (Eds.), International Handbook of Underwater Archaeology. Kluwer Academic/Plenum, New York, pp. 697-714.

MacLeod, I.D., 2013. Monitoring, modelling and prediction of corrosion rates of historical iron shipwrecks. In: Watkinson, D., Angelini, E., Adriaens, A. (Eds.), Corrosion and Conservation of Cultural Heritage Metallic Artefacts, Dillmann. EFC no. 65, Woodhead Publishing, pp. 466-477.

MacLeod, I.D., Steyne, H., 2011. Managing a Monitor - The case of HMVS Cerberus in Port Phillip Bay: Integration of Corrosion Measurements With Site Management Strategies, Management of Archaeological Sites. vol. 13(4) pp. 334-361.

Masi, B.P., Macedo, I.M., Zalmon, J.R., 2009. Annual and spatial variation of intertidal benthic community zonation in a breakwater off the Rio de Janeiro coast, south-eastern Brazil. J. Mar. Biol. Assoc. U. K. 89, 225-234.

MoSS Project, 2004. http://www.mossproject.com/.

Mumme, W.G., Tsambourakis, G., Madsen, I.C., Hill, R.J., 1996. Improved petrological modal analyses from X-ray powder diffraction data by use of the Rietveld method. Part II: selected sedimentary rocks. J. Sediment. Res. 66 (1), 132-138.

Neff, N., Dillmann, P., Bellot-Gurlet, L., Beranger, G., 2005. Corrosion of iron archaeological artefacts in soil: characterisation of the corrosion system. Corros. Sci. 47, 515-535.
Neff, N., Dillmann, P., Descostes, M., Beranger, G., 2006. Corrosion of iron archaeological artefacts in soil: estimation of the average corrosion rates involving analytical techniques and thermodynamic calculations. Corros. Sci. 48, 2947-2970.

Nikon NIS-Elements Advanced Research, 2014. User's Guide-ver. 4.0.

North, N.A., 1976. Formation of coral concretions on marine iron. Int. J. Naut. Archaeol. Underw. Explor. 5 (3), 253-258.

Oxley, I.N., 1996. The in-situ preservation of underwater sites. In: Corfield, M., Hinton, P., Nixon, T., Pollard, M. (Eds.), Preserving Archaeological Remains In Situ (PARIS1). Museum of London Archaeology Service, London, pp. 159-173.

Palma, P., 2005. Monitoring of shipwreck sites. Int. J. Naut. Archaeol. 34, 323-331.

Pearson, C., 1987. Conservation of Marine Archaeological Objects. Butterwoth\&Co, London.

Pourbaix, M., 1963. In: Gauthiers-Villars (Ed.), Atlas d'équilibres électrochimiques à 25C Université de Bruselles, Paris (664 pp.).

Pournou, A. Jones, A.M. Moss, S.T., 1998. In: Hoffmann, P.. Bonnot-Diconne, C. Hiron, X. Tran, Q.K. (Eds.), The 7th ICOM-CC Working Group on Wet Organic Archaeological Materials Conference. ICOM, Grenoble, pp. 58-64.

Preskitt, L.B., Vroom, P.S., Smith, C.M., 2004. A rapid ecological assessment (REA) quantitative survey method for benthic algae using photoquadrats with scuba. Pac. Sci. 58, 201-209.

Quinn, R., Boland, D., 2010. The role of time-lapse bathymetric surveys in assessing morphological change at shipwreck sites. J. Archaeol. Sci. 37, 2938-2946.

RAAR Project, 2005. http://www9.vgregion.se/vastarvet/svk/reburial/index.htm.

Radzikowska, J.M., 2004. Metallography and microstructures of cast iron. In: Vander Voort, George F. (Ed.), Metallography and Microstructures, ASM Handbook 9. ASM International, New York, pp. 565-587.

Railkin, A.I., 2004. Marine Biofouling. Colonization Processes and Defenses. CRC press.

Refait, P., Génin, J.M.R., 1997. The Mechanisms of Oxidation of Ferrous Hydroxychloride $\beta-$ $\mathrm{Fe}_{2}(\mathrm{OH})_{3} \mathrm{Cl}$ in Aqueous Solution: The Formation of Akaganeite vs Goethite. 39 pp. 539-553.

Refait, P., Abdelmoula, M., Génin, J.M.R., 1998. The mechanisms of formation of Green Rust in aqueous corrosion of iron in the presence of chloride ions. Corros. Sci. 40, 1547-1560.

Réguer, S., Dillmann, P., Mirambet, F., 2007. Buried iron archaeological artefacts: corrosion mechanisms related to the presence of $\mathrm{Cl}$-containing phases. Corros. Sci. 49 $2726-2744$.

Réguer, S., Mirambet, F., Dooryhee, E., Hodeau, J.L., Dillmann, P., Lagarde, P., 2009. Structural evidence for the desalination of akaganeite in the preservation of iron archaeological objects, using synchrotron X-ray powder diffraction and absorption spectroscopy. Corros. Sci. 51 (2009), 2795-2802.

Réguer, S., Mirambet, F., Rémazeilles, C., Vantelon, D., Kergourlay, F., Neff, D., Dillmann, P. 2015. Iron corrosion in archaeological context: structural refinement of the ferrous hydroxychloride $\beta-\mathrm{Fe}_{2}(\mathrm{OH})_{3} \mathrm{Cl}$. Corros. Sci. 100, 589-598.

Riess, W., Daniel, G., 1997. Evaluation of preservation efforts for the Revolutionary War privateer Defence. Int. J. Naut. Archaeol. 26, 330-338.

Ruxanda, R., Stefanescu, D.M., 2004. Solidification structures of steels and cast irons. In: Vander Voort, George F. (Ed.), Metallography and Microestructures, ASM Handbook 9. ASM International, New York, pp. 97-106.

Samuels, L.E., 1992. Australia's contribution to archaeometallurgy. Mater. Charact. 29 (2), 69-109.

SASMAP project, 2015. http://www.sasmap.eu.

Schiffer, M.B., 1983. Toward the identification of formation processes. American Antiquity]->Am. Antiq. 48, 675-706.

Schiffer, M.B., 1987. Formation Processes of the Archaeological Record. 1987. University of New Mexico Press, Albuquerque.

Selwyn, L.S., 2004. Overview of archaeological iron: the corrosion problem, key factors affecting treatment, and gaps in current knowledge. In: Ashton, J., Hallam, D. (Eds.) METAL04, Proceedings of the International Conference on Metals Conservation. National Museum of Australia, Canberra, pp. 294-306.

Selwyn, L.S., Sirois, P.J., Argyropoulos, V., 1999. The corrosion of excavated archaeological iron with details on weeping and akaganeite. Stud. Conserv. 44, 217-232.

Stewart, J., Murdock, L.D., Waddell, P., 1994. Reburial of the Red Bay wreck as a form of preservation and protection of the historic resource. In: Vandiver, P.B., Druzik, J.R. Madrid, J.L.G., Freeston, I.C., Wheeler, G.S. (Eds.), Materials Issues in Art and Archaeology IV, Materials Research Society Symposium Proceedings. Materials Research Society, Pennsylvania, pp. 791-805.

Thomson, R.E., Emery, W., 2014. Data Analysis Methods in Physical Oceanography. 3rd edition. Elsevier

Turgoose, S., 1982. Post-excavation changes in iron antiquities. Stud. Conserv. 27, 97-101.

UNESCO, 2001. The UNESCO convention on the protection of the underwater cultural heritage. Gen Conf United Nations Educ Sci Cult Organ Meet Paris From 15 Oct to 3 Novemb 2001, Its Thirty-first Sess. vol. 1, p. 180 (Paris).

Van Rein, H., Schoeman, D.S., Brown, C.J., Quinn, R., Breen, J., 2011. Development of benthic monitoring methods using photoquadrats and scuba on heterogeneous hardsubstrata: a boulder-slope community case study. Aquat. Conserv. Mar. Freshwat. Ecosyst. 21, 676-689.

Van Rein, H., Schoeman, D.S., Brown, C.J., Quinn, R., Breen, J., 2012. Development of lowcost image mosaics of hard-bottom sessile communities using SCUBA: comparisons of optical media and of proxy measures of community structure. J. Mar. Biol. Assoc. U. K. 92, 49-62.

Wranglén, G., 1985. Korrosion und Korrosionsschutz. Springer-Verlag, Berlin.

Young, R.A., Prince, E., Sparks, R.A., 1982. Suggested guidelines for the publication of Rietveld analyses and pattern decomposition studies. J. Appl. Crystallogr. 15, 357-359. 